\title{
THE EFFECT OF FISCAL POLICY ON BANKS' FINANCIAL REPORTING
}

\author{
A Dissertation \\ Presented to the Faculty of the Graduate School \\ of Cornell University \\ in Partial Fulfillment of the Requirements for the Degree of \\ Doctor of Philosophy
}

by

Felipe Bastos Gurgel Silva

August 2018 
(C) 2018 Felipe Bastos Gurgel Silva

ALL RIGHTS RESERVED 


\section{THE EFFECT OF FISCAL POLICY ON BANKS' FINANCIAL REPORTING}

Felipe Bastos Gurgel Silva, Ph.D.

Cornell University 2018

This dissertation documents the effect of governments' fiscal policy on banks' loan loss provisions. Governments' deficits are inversely related to the credibility and strength of implicit guarantees granted to the banking sector, affecting the tail risk properties of banks' loan portfolios. I predict and find a positive relation between governments' deficits and banks' loan loss provisions. The fiscal effect is statistically and economically stronger than the relationship between business cycles and banks' loan loss provisions, and is moderated by the country's debt-to-GDP ratio. My results are robust to different sample partitions and after controlling for potentially confounding effects. To address endogeneity concerns between fiscal policy, business cycles, and banks' financial reporting decisions, I identify fiscal shocks by estimating innovations to governments' military expenditures. Results from an instrumental variables approach support the association between fiscal shocks and banks' loan loss provisions. Taken together, my results shed light on how fiscal policy decisions affect banks' financial reporting choices. 


\section{BIOGRAPHICAL SKETCH}

Felipe Bastos Gurgel Silva was born in Fortaleza, Brazil, on May 11, 1983. He received his undergraduate degree in Aeronautical Engineering from Instituto Tecnológico de Aeronáutica (ITA), Brazil, in 2006. Upon the completion of his engineering studies, he began his professional career in the private sector at the aircraft manufacturer Embraer. Later, he pursued a career in the financial services industry, serving as a market risk modeling analyst at Itaú Unibanco Holding and as a quantitative research analyst with the proprietary trading desk at Banco Stantander. He was also a founding partner of a start-up enterprise in the telecommunications sector, later sold to a large retailer. Prior to his doctoral studies at Cornell, he also pursued an M.Eng. in Financial Engineering from Cornell's School of Operations Research and Information Engineering. He is married to Anna Paula and the father of Eric. He will join the Trulaske College of Business of the University of Missouri as an assistant professor in the Fall semester of 2018. 
To Anna Paula and Eric 


\section{ACKNOWLEDGEMENTS}

The higher we soar, the smaller we appear to those who cannot fly.

— Friedrich Nietzsche

Although the title page of this dissertation bears only one name, it is a matter of fairness to acknowledge the unswerving and indispensable support of family, fellow students, and professors without which I could not have succeeded. First, I shall never be able to repay my parents, Fátima and Marcelo, for their most precious and enduring gift: their magnificent genes. I extend my gratitude to my brother André and to my whole family.

I am enormously thankful to my advisers, Robert Jarrow and Sanjeev Bhojraj, for their invaluable feedback during my graduate studies and their unconditional support whenever my intellectual curiosity drove me towards unorthodox questions. I am also grateful to Warren Bailey, Kenneth Merkley, George Gao, Murillo Campello, Robert Libby, and Mani Sethuraman, for their professional guidance and personal advice.

Being a doctoral student for five years meant spending countless hours in a PhD office at Cornell crammed with papers and coffee mugs. I am therefore immensely thankful to my friends and fellow $\mathrm{PhD}$ students who shared with me the excitement and frustrations that make the academic career so vibrant. I thank Piyush Anand, Junhyun Bae, Jialie Chen, Manuela Dantas, Michael Durney, Hassan Ilyas, Gaurav Kankanhalli, Dawoon Kim, Chuchu Liang, M. Pradeep, Blake Steenhoven, and Ekaterina Volkova. I am grateful to Annie Johnston for her attention and support when I most needed it.

Completing a doctoral program is a challenging endeavor, but it would have been much harder if I had not had the opportunity to study in an undergraduate 
school whose academic standards are paralleled by few. I therefore thank the Instituto Tecnológico de Aeronáutica (ITA), its faculty and former classmates I have had the honor to call friends for more than fifteen years: Pedro Di Donato, Alexandre Gama, Pedro Gouveia, Diego Oliveira, and Guilherme Pimentel, to name a few. I am also indebted to Jeandson Lopes for being a moderator to my most extreme impulses, and to my childhood friends from Fortaleza, Brazil.

Above all, every minute of work during these years was a minute I could not spend with my wife Anna Paula and my son Eric. I could never express in words how their love and patience have been the foundation of my motivation and passion. 


\section{TABLE OF CONTENTS}

Biographical Sketch . . . . . . . . . . . . . . . . iii

Dedication ..................... iv

Acknowledgements . . . . . . . . . . . . . . . . v v

Table of Contents . . . . . . . . . . . . . . . . . . . . vii

List of Tables . . . . . . . . . . . . . . . . . . . . . . . viii

List of Figures $\ldots \ldots \ldots \ldots \ldots \ldots \ldots \ldots$ ix

1 The Effect of Fiscal Policy on Banks' Financial Reporting 1

1.1 Introduction $\ldots \ldots \ldots \ldots \ldots \ldots \ldots \ldots \ldots$

1.2 Prior Literature and Hypotheses Development . . . . . . . . . 8

1.2.1 Banks' Loan Loss Provisions and Business Cycles . . . . . 8

1.2.2 Government Guarantees . . . . . . . . . . . . . . . . . 10

1.2.3 Fiscal Policy and Banks' Real Outcomes . . . . . . . . . . . 12

1.2.4 Analytical Framework . . . . . . . . . . . . . . . . . . . . . 14

1.2.5 Hypotheses Development . . . . . . . . . . . . . . . . . 19

1.3 Empirical Results . . . . . . . . . . . . . . . . . . 23

1.3.1 Data Description and Sample Selection . . . . . . . . . 23

1.3.2 Fiscal Policy, Business Cycle and Loan Loss Provision . . . 29

1.3.3 Fiscal Policy Interaction with Debt-to-GDP . . . . . . . . 37

1.4 Instrumental Variables Estimation: Levels and Innovations of Defense Expenditures . . . . . . . . . . . . . . . . . 41

1.4.1 Identifying Fiscal Shocks . . . . . . . . . . . . . . 41

1.4.2 Deficits and Loan Loss Provisions: IV Estimation . . . . . 48

1.4.3 Analysis of Exclusion Restriction . . . . . . . . . . . . . 53

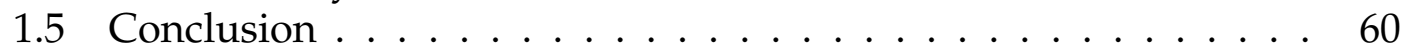

$\begin{array}{ll}\text { A Variable Definitions } & 62\end{array}$

B Additional Analyses $\quad 64$

B.1 Lagged Effects of Fiscal Policy and Business Cycles . . . . . . . . 64

B.2 Controlling for Additional Macroeconomic and Geopolitical Vari-

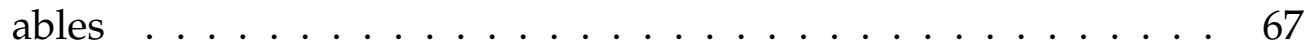




\section{LIST OF TABLES}

1.1 Sample Selection - Sequential Filters . . . . . . . . . . . . . 26

1.2 Sample Description by Country . . . . . . . . . . . . . 27

1.3 Summary Statistics - Bank-specific and Macroeconomic Variables 28

1.4 Summary Statistics - Correlation Matrix . . . . . . . . . . . . 29

1.5 Fiscal Policy and Business Cycles - Main Result . . . . . . . . . 34

1.6 Fiscal Policy and Business Cycles - Geographic Partitions . . . . 35

1.7 Fiscal Policy and Business Cycles - Results Interacting with Overprovisioning Behavior $\ldots \ldots \ldots \ldots \ldots \ldots$

1.8 Fiscal Policy and Business Cycles - Results Interacting with Debt-to-GDP . . . . . . . . . . . . . . . . . . . . 40

1.9 Instrumental Variables Estimation — First-stage Coefficient Estimates. . . . . . . . . . . . . . . . . . 51

1.10 Instrumental Variables Estimation - Second-stage (2SLS) Estimates ........................... 52

1.11 Defense Expenditures and Future Nonperforming Loans . . . . . 55

1.12 Defense Innovations, Deficits, and Loan Loss Provisions . . . . 56

A.1 Variable Definitions . . . . . . . . . . . . . . . . . . 62

B.1 Fiscal Policy and Business Cycles - Result Including Lagged Terms ........................ 66

B.2 Fiscal Policy and Business Cycles - Additional Controls . . . . 70 


\section{LIST OF FIGURES}

1.1 Relationship between Business Cycles and Fiscal Policy $\ldots . .7$

1.2 Tail Risk Effect of Government Guarantees . . . . . . . . . . . 16

1.3 Direct Channel, Indirect Channels, and Competing Hypotheses . 22

1.4 Defense Spending Levels and Innovations — United States . . . 45

1.5 Defense Spending Levels and Innovations — France . . . . . . 46

1.6 Defense Spending Levels and Innovations — India . . . . . . . 47

1.7 Defense Spending Levels and Innovations - Singapore . . . . . 48

1.8 Jordà (2005) Local Projections . . . . . . . . . . . . . . . . . . . 59 
CHAPTER 1

THE EFFECT OF FISCAL POLICY ON BANKS' FINANCIAL REPORTING

\subsection{Introduction}

Banks play a uniquely important role in the economy through their primary function of financial intermediation, facilitating the allocation of capital among different economic agents. Consequently, the interaction between bank-specific real and financial reporting variables and the macroeconomy are particularly important to regulators, policy makers, and standard setters. Given banks' inherent business complexity and opaque financial reports, the quality of the information provided by managers is central to the efficacy of the sector and the stability of the financial system in downturns (Diamond and Dybvig, 1983; Diamond and Rajan, 2001; Morgan, 2002; Flannery, Kwan, and Nimalendran, 2004; Acharya and Ryan, 2016). In this paper, I uncover a macroeconomic channel that affects banks' provisioning decisions - the fiscal policy effect, which operates through the strength of implicit government guarantees to the banking system.

The loan loss provision is one of the most important financial items of an institution primarily engaged in lending, as it represents an expense account which is set up by bank managers as a buffer reflecting possible losses in their loan portfolios. It typically corresponds to one of the main items of a bank's income statement, is highly subject to managerial discretion, and is strongly correlated with the bank's regulatory capital ratios and net income (Laeven and Majnoni, 2003; Bikker and Metzemakers, 2005; Fonseca and González, 2008; 
Pérez, Salas-Fumás, and Saurina, 2008; Gebhardt and Novotny-Farkas, 2011) ${ }^{1}$

Since the objective of this variable is primarily to reflect possible credit losses, bank managers who observe noisy signals regarding the creditworthiness of their banks' individual loans consider both bank-specific and macro-economic factors as incrementally informative of future credit losses. ${ }^{2}$

The economic justification for why macroeconomic variables representing business cycles may be informative of banks' loan loss provisioning after controlling for bank-specific variables is straightforward. Since business cycles signal information of possible (future) defaults in banks' lending assets, bank managers can infer additional distributional properties of the forward-looking values of banks' performing loans from such aggregate variables. However, given the unique importance of government guarantees to the banking industry, ${ }^{3} \mathrm{I}$ hypothesize that governments' fiscal deficits (or surpluses) should also represent an important state variable for banks' credit risk and affect bank managers' reporting choices since the strength and credibility of implicit guarantees are inherently linked to governments' fiscal conditions (Acharya et al., 2014; Brunnermeier et al., 2016). The presence of government guarantees represents an

\footnotetext{
${ }^{1}$ Rules governing banks' loan loss provisioning and reserves require a balance between the goals of bank regulators, who emphasize safety and financial stability, and the goals of standard setters, who emphasize the transparency of financial statements (Balla et al., 2012)

${ }^{2} \mathrm{~A}$ vast literature empirically shows that the levels of loan loss provision are associated with both bank-specific characteristics (e.g., past- present- and forward-looking risk levels of the bank's loan portfolio, capital ratios, etc.) and aggregate economic variables. Specifically on the links between macroeconomic conditions and banks' loan loss provisions, the literature has shown that banks tend to report less (more) provision for loan losses in periods of economic expansion (contraction), reflected by business cycle proxies such as GDP, Real Estate Prices, Unemployment Rates, etc.

${ }^{3}$ As highlighted by Calomiris and Haber (2014), "there is no avoiding the governmentbanker relationship." From a production function standpoint, a bank's main inputs (deposits) and outputs (loans) are essentially debt contracts, making its business model inherently risky and relying on the enforcement power of the state. Only the government can provide the guarantees capital providers need to subsequently finance a bank's assets and such guarantees can only be credible provided governments are fiscally stable to provide the financial backing necessary to a well-functioning banking sector.
} 
extra layer of protection in high marginal utility states. Such guarantees affect the lower tail of the distribution of the terminal values of banks' assets and the strength of their credibility is contingent on governments' budgetary conditions. Holding constant the financial reporting incentives bank managers are subject to, a deterioration in the fiscal deficit of a government reduces the strength of its guarantees to banks, therefore increasing the range of possible losses due to nonperforming assets in the future, which are no longer protected by these guarantees. This effect is particularly strong when bank managers face asymmetric reporting incentives to over-provision rather than under-provision.

Using a large sample of banks from 47 countries I show that when governments' fiscal conditions deteriorate (widening deficits or shrinking surpluses), banks increase their loan loss provisions. Although the effect is directionally similar to the comovement of loan loss provisions with the business cycle, the fiscal policy effect is, surprisingly, both statistically and economically stronger. While a one standard deviation decrease in a country's GDP per capita is, on average, associated with a $8.36 \%$ standard deviation increase in banks' loan loss provisions, a one standard deviation increase in a country's deficit (or decrease in surplus) corresponds to a $25.71 \%$ standard deviation increase in banks' loan loss provisions. Sample partitions based on different geographies show that the fiscal effect is statistically significant for all subgroups of banks, while estimates of the business cycle effect are mixed in terms of their significance and even their sign. Consistent with the hypothesis that the effect arises jointly from banks' reporting incentives and variation in the strength of government guarantees, I find that this association is stronger for banks which ex-ante have consistently been conservative in their provisioning decisions. Moreover, I show that the positive association between deficits and banks' provisioning is amplified by the 
indebtedness of the corresponding country (proxied by the country's debt-toGDP ratio).

At this juncture, it is important to note that statistical associations between governments' deficit and banks' provisioning and the amplification effect by countries' indebtedness are empirically consistent with both direct and indirect effects of fiscal policy. In this particular setting, both business cycles and fiscal policy choices represent macroeconomic constructs which are naturally intertwined, therefore demanding additional analyses to disentangle effects originated by fiscal policy from the well-documented association between banks' loan loss provisions and business cycles. In a simplified framework, different levels of economic output (business cycle) induce the government to make fiscal policy decisions (therefore affecting the government's finances by construction) whose main objective is to affect business cycles - i.e., economic output and employment, as originally proposed by Keynes (1937). Not only are the business cycle and the governments' finances cyclically determined, but they may also be jointly affected by other macroeconomic or geopolitical factors. ${ }^{4}$ Figure 1.1 summarizes the relationship between these variables. In other words, I expect fiscal policy choices to affect bank managers' assessment of credit risk, and consequently banks' loan loss provisions, through two different channels. In the first one (the direct channel, hereafter) fiscal policy decisions reflected in the government's deficit have a direct effect on the strength of government guarantees, which in turn affects managers' assessment of tail risk. In the second channel, fiscal policy choices lead to intended and unintended effects on business cycles or other macroeconomic variables that ultimately affect banks' provisioning

\footnotetext{
${ }^{4}$ For example, the election of a populist candidate can be followed by aggressive fiscal policies (e.g., lower taxation and more government spending), which consequently widen fiscal deficits.
} 
without necessarily affecting the strength of government guarantees (hence, an indirect channel). The indirect channel can also operate through expected effects, in addition to actual effects, on business cycles. For example, widening deficits may hurt the government's credibility to utilize fiscal policy as an instrument to stimulate the economy in response to future negative business cycle shocks.

To further address concerns regarding the endogenous nature of fiscal policy, I employ an instrumental variables approach where countries' government finances are instrumented both by levels and innovations of military and defense expenditures. Military expenditures represent one component of the spending side of the governments' finances whose levels are typically defined by governments based on geopolitical and strategic factors largely unrelated to business cycles. A growing body of literature has used the approach of identifying fiscal shocks through surprises in defense expenditures (Ramey and Shapiro, 1998; Ramey, 2011; Berndt, Lustig, and Yeltekin, 2012). As in Ramey (2011) and Ramey and Shapiro (1998), I do not argue that military expenditures are exogenous per se, but rather that innovations ${ }^{5}$ to military expenditures are exogenous with respect to omitted variables that potentially affect banks' financial reporting choices through a channel other than the fiscal policy of their respective governments. I estimate innovations to military expenditures by fitting different specifications of vector-autoregressive models and show that the positive association between governments' deficits and the provisioning of banks is still statistically and economically significant. Although empirical results relating fiscal shocks and banks' loan loss provisions are consistent with effects partially stemming from indirect channels - i.e, fiscal shocks may still have both actual and expected effects on business cycles leading to banks' provisioning decisions

\footnotetext{
"Innovations" in this context refers to the fraction of defense expenditures which are not explained by a time-series econometric model.
} 
— they provide cleaner evidence of the direct channel of fiscal policy hitherto undocumented in the literature.

Taken together, the contributions of my work to the literature are twofold. First, this paper contributes to the vast literature on the cyclicality of banks' capital requirements by documenting a statistically and economically relevant macroeconomic variable that helps to explain the time-series and cross-sectional variation of banks' loan loss provisions in a large set of banks. Understanding what economic forces drive the dynamics of banks' loan loss provisioning is crucial to enhancing the stability of the banking sector. For example, a prior study documents that if a model of dynamic provisioning similar to the one adopted by the Spanish regulatory authority were implemented in the United States, the subsequent fiscal costs of the TARP program would have been substantially lower. ${ }^{6}$

Second, this paper contributes to the voluminous finance and economics literature on implicit government guarantees granted to the banking sector (O'Hara and Shaw, 1990; Kelly, Lustig, and Van Nieuwerburgh, 2016; Gandhi and Lustig, 2015) and the nascent literature on how such guarantees affect banks' financial reporting decisions. A contemporaneous paper related to my work is Dantas, Merkley, and Silva (2018), which documents a negative association between government guarantees and banks' earnings management. My paper adds to that work in two different ways. First, while in Dantas et al. (2018)

\footnotetext{
${ }^{6}$ Dynamic provision is often regarded as a macro-prudential policy instrument to counter the pro-cyclicality of banks' credit provisions. Under the Spanish dynamic provisioning system, overall provisions are defined as a combination of specific provisions and the variation of the bank's loan portfolio. Jiménez et al. (2017) find that dynamic provisioning smooths credit supply cycles and supports banks' performance in bad times. Fillat and Montoriol-Garriga (2010) conclude that about half of the commercial banks which received TARP funds would not have needed them if the dynamic provisioning system had been in place in the U.S. during the Subprime crisis.
} 
we study the effect of government guarantees on the discretionary use of loan loss provisions with the purpose of income smoothing (i.e., the statistical association between banks' loan loss provisions and earnings before the provisioning of this accrual), my work focuses on the magnitude of the provisions themselves. Second, while their work exploits two quasi-natural experiments representing exogenous shocks to explicit and implicit guarantees, I study the effect of government guarantees through the particular channel of governments' fiscal policy.

- Direct effects on the government's finances

- Economic policies are adopted in response to business cycles

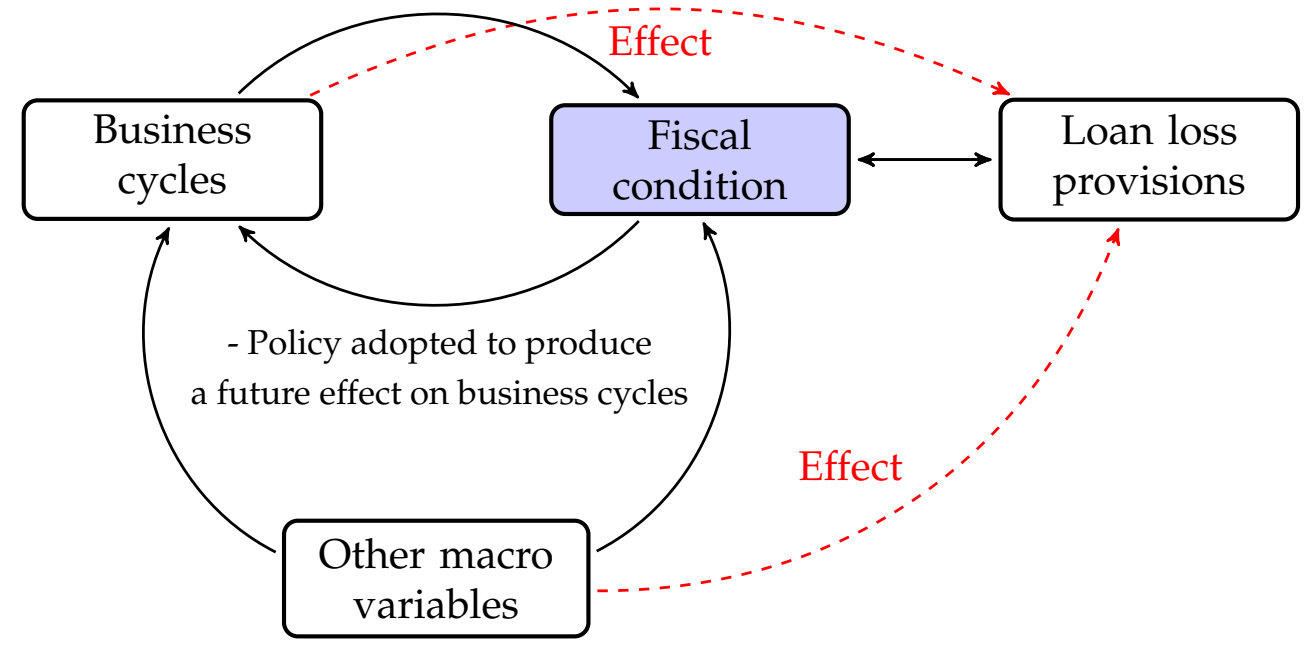

Figure 1.1: Relationship between Business Cycles and Fiscal Policy 


\subsection{Prior Literature and Hypotheses Development}

\subsubsection{Banks' Loan Loss Provisions and Business Cycles}

The loan loss provision is arguably the main accrual of a bank, comprising on average $56 \%$ of a bank's total accruals (Beatty and Liao, 2014). It is highly subject to managerial discretion, as it is strongly correlated with capital ratios and operational income (Greenawalt and Sinkey, 1988; Beatty, Chamberlain, and Magliolo, 1995; Collins, Shackelford, and Wahlen, 1995; Ahmed, Takeda, and Thomas, 1999; Laeven and Majnoni, 2003; Bikker and Metzemakers, 2005; Fonseca and González, 2008; Pérez, Salas-Fumás, and Saurina, 2008; Gebhardt and Novotny-Farkas, 2011).7 Beaver, Eger, Ryan, and Wolfson (1989) document that the level of loan loss reserves is positively associated with the market value of the bank's equity, suggesting that managers use this accrual to convey information to market participants of how the bank's earnings can withstand large loan loss provisions. Beaver and Engel (1996) provide supporting evidence of the signalling hypothesis of this accrual by showing that this positive association is driven by the discretionary component of the loan loss provision.

Empirical evidence on the relationship between the loan loss provision of banks and the business cycle was documented by Liu and Ryan (2006), which shows that financially weak banks delayed loss recognition on heterogeneous loans during the pre-1990 bust period while profitable banks accelerated chargeoffs of homogeneous loans in the pre-1990 boom period. Their results are consis-

\footnotetext{
${ }^{7}$ Although the loan loss provision is typically the bank's main accrual, banks can also engage in earnings and capital management by exploiting additional items and accounting rules. Barth et al. (2016) show that banks use realized available for sale (AFS) securities gains and losses to smooth earnings and increase low regulatory capital.
} 
tent with an income smoothing hypothesis, which, if taken in isolation, would suggest a positive relationship between business cycles and banks' loan loss provisions, since banks' profitability is positively associated with real economic output. However, different empirical results show that, after controlling for the discretionary component of the loan loss provision due to income smoothing incentives, there is indeed a negative relationship between business cycles and banks' loan loss provisions - i.e., banks tend to provision less (more) than what should be expected given their operational performance and loan portfolio quality during economic booms (busts). Beatty and Liao (2014) show that under different choices of provision models this variable is negatively associated with GDP growth and real estate prices, but positively associated with changes in unemployment.

Another body of literature argues that business cycles not only influence the levels of loan loss provisions but also affect the timeliness of the item in reflecting forward-looking information. Bhat et al. (2013) document that banks relying more on statistical methods to manage risks of their loan portfolios (rather than stress tests) are more timely in recognizing losses before and during the Subprime financial crisis. Banks using stress tests are, however, more timely in recognizing losses in the early stages of the crisis. Bushman and Williams (2015) show that delays in loss recognition are positively associated with different dimensions of bank-specific and systematic risk, as such delays increase banks' vulnerability to downside risk. This association is particularly observable in periods of economic bust (and insignificant for periods of economic expansion). Beatty and Liao (2011) provide evidence that banks that delay the recognition of losses are more likely to reduce lending during recessions, thereby amplifying the pro-cyclicality of bank credit. 
More recently, Dewatripont and Tirole (2012) showed that in the presence of macroeconomic shocks, self-insurance mechanisms such as countercyclical capital buffers and dynamic provisioning are desirable. These theoretical insights are corroborated by the results of Jiménez et al. (2017).

\subsubsection{Government Guarantees}

Because of their importance to the whole economy and due to their specific economic features (highly leveraged balance sheet, regulated capital, and core activity of financial intermediation), banks rely on the power of the state to establish an environment of contract enforceability and provide government guarantees to economic agents holding their contingent claims. Without the implicit and explicit presence of government guarantees, the willingness of depositors and capital market participants to become capital providers is compromised and the whole economy may become under-banked (Calomiris and Haber, 2014).

Government guarantees represent the financial backing from the government that different capital providers of the banking sector have in case the bank is unable to meet its financial obligations. Consequently, government guarantees are directly linked to the risk and pricing of contingent claims on the assets of individual banks and the banking sector. While such guarantees are generally seen as welfare improving, in that they induce banks to provide more liquidity, they may also increase the probability of bank runs because of moral hazard problems (Allen et al. 2017).

A seminal paper that documents the valuation effect of government guar- 
antees on banks' equity prices is $\mathrm{O}^{\prime}$ Hara and Shaw (1990), which studies the abnormal market reaction of equity prices of banks which were explicitly labeled by the Comptroller of the Currency as being "too-big-to-fail". More recently, Gandhi and Lustig (2015) uncovered a "size" priced factor specific to the banking sector in the United States and orthogonal to the well documented "small-minus-big" size factor (i.e., a too-big-to-fail risk factor in bank equity prices). Evidence of the effect of government guarantees on banks' debt is also documented (Acharya, Aginer, and Warburton, 2016).

Pricing and risk effects of government guarantees are not only observed in securities of individual banks but also documented for the whole banking sector. Kelly, Lustig, and Van Nieuwerburgh (2016) show a pricing effect on put option prices on the financial sector index, which is cheaper relative to put options written on its member banks. They develop a structural model incorporating disaster risk and show that only the presence of government guarantees can explain the cheaper price paid to insure the whole financial sector relative to individual banks.

Government guarantees are shown not only to have effects on securities prices and risk but also on banks' real and reporting outcomes, including risktaking behavior (Stern and Feldman, 2004: Gropp, Gruendl, and Guettler, 2013; Fischer, Hainz, Rocholl, and Steffen, 2014), cyclicality of equity issuance (Baron, 2016), and earnings management (Dantas et al., 2018). 


\subsubsection{Fiscal Policy and Banks' Real Outcomes}

The relationship between the fiscal policy conducted by a government and banks' real and reporting outcomes is conceptually outlined through the channel of government guarantees. Both explicit and implicit guarantees are, theoretically speaking, wealth transfers from the government to the different capital providers of banks in high marginal utility states. Since the contingent obligations bankers have with the holders of their claims become, in such states, government liabilities, such guarantees will be credibly stronger with healthier government finances.

The literature provides theoretical and empirical evidence linking the fiscal situation and creditworthiness of the government and banks' real outcomes. Acharya, Drechsler, and Schnabl (2014) develop a theoretical framework with a banking sector, a non-financial sector, and a government to model the loop between the sovereign risk of the government and the credit risk of the banks. When banks face financial distress, government bailouts are induced and, consequently, the government's creditworthiness deteriorates. Worsening sovereign risk erodes the value of government guarantees (fiscal policy effect). Applying their model to the CDS data during the Eurozone credit crisis of the late 2010's, they show that post-bailout changes in sovereign CDS rates have explanatory power on bank-specific CDS rates. Brunnermeier et al. (2016) model the "diabolic loop" between sovereign and bank credit risk, which was the epicenter of the Eurozone credit crisis.

Correa, Lee, Sapriza, and Suarez (2014) study the relationship between expected government support and changes in credit ratings of sovereign bonds on bank stock returns in a large sample of international banks. They show that 
sovereign downgrades from credit rating agencies have a strong negative effect on stock prices for banks which are more expected to receive government support, emphasizing the channel of government guarantees. They show that this effect is also moderated by banks from countries which are better financially positioned to provide government support.

More recently, Gandhi, Lustig, and Plazzi (2016) generalized the finding of Gandhi and Lustig (2015) that equity of large financial institutions earns lower adjusted returns to a larger set of international financial institutions. They also show that this effect is stronger the better the finances of the country's government are.

I hypothesize that while deteriorating fiscal deficits weaken government guarantees and amplify the possible range of nonperforming assets of a financial institution, this real effect interacts with bankers' reporting incentives already in place and generates an additional source of comovement in banks' provisioning. The economic mechanism of this direct channel can be described as follows. Bank managers' decisions to report loan loss provisions are made before the realization of what fraction of their banks' assets will be nonperforming in the subsequent period. Therefore, they provide their estimates based on bank-specific and macroeconomic variables knowing that capital markets may reward them for their precision (i.e., provisioning an amount that is close to the realized value of nonperforming assets) but also differentially punish them for aggressive reporting (i.e., controlling for the same magnitude of imprecision, over-provisioning is preferred to under-provisioning).

Holding the strength of government guarantees constant, the fact that overprovisioning and under-provisioning are seen differentially by capital market 
participants naturally creates a bias for bank managers to avoid aggressive under-provisioning.

In the next subsection I develop an analytical framework to illustrate how the tail risk factor arising from the government's ability to financially back losses of banks' assets interacts with bankers' reporting incentives, creating an additional comovement term on banks' provisioning.

\subsubsection{Analytical Framework}

I propose an analytical framework ${ }^{8}$ to illustrate how the introduction of the bank manager's reporting cost function, which accounts for the imprecision and accounting aggressiveness in the reporting of a bank's nonperforming assets, leads to a direct relation between the strength of the guarantees provided by the government and the bank's under- (or over-) provisioning.

This setting can be extrapolated as a static game involving the manager of a bank whose terminal (liquidation) value of its assets $A$ is uncertain and its capital providers (depositors, debtholders, and equity holders) extract utility from the quality of the manager's assessment of the creditworthiness of its assets (loan portfolio) ${ }^{9}$ For the sake of simplicity I consider that, absent government guarantees - i.e., considering only the risk characteristics of the banks' assets - the terminal value of $A$ is represented by a random variable uniformly dis-

\footnotetext{
${ }^{8}$ I use the term "framework" rather than "model" because in this setting the only endogenous variable is the bank manager's decision to report an estimate of the performing assets. All the other variables of the framework (i.e., the risk of the bank's assets, the reporting function of the managers and the level of government guarantees) are exogenous.

${ }^{9}$ In this framework only the reporting quality of the bank's manager is included since other capital market benefits will be a direct function of the exogenous level of government guarantees and the endogenous choice of banks' risk taking (represented by parameters $\bar{A}$ and $\sigma$ ).
} 
tributed over the interval $[\bar{A}-\sigma, \bar{A}+\sigma]$. This distribution is illustrated in the upper plot of Figure 1.2. The introduction of an exogenous level of government guarantees is represented by the maximum quantity $g_{0}$ of the bank's assets that can be backed up by the government in case of default. ${ }^{10}$ It degenerates the uniform distribution such that any realization of $A$ between $\bar{A}-\sigma$ and $\bar{A}-\sigma+g_{0}$ is mapped into the same value of $\bar{A}-\sigma+g_{0}$, leading to a mass probability of $\frac{g_{0}}{2 \sigma}$ on this value. The probability density function of $A$ after the introduction of government guarantees $g_{0}$ is depicted in the second plot of Figure 1.2 .

\footnotetext{
${ }^{10}$ It is important to note that in this framework the extra layer of protection provided by $g_{0}$ abstracts from whether lenders (banks) or borrowers are receiving such capital infusions. In other words, $g_{0}$ represents a "tail risk" effect which may come from the ability of the government to bail out banks (direct channel) or its ability to indirectly bail out the borrowers, thereby stimulating the economy (indirect channel)
} 

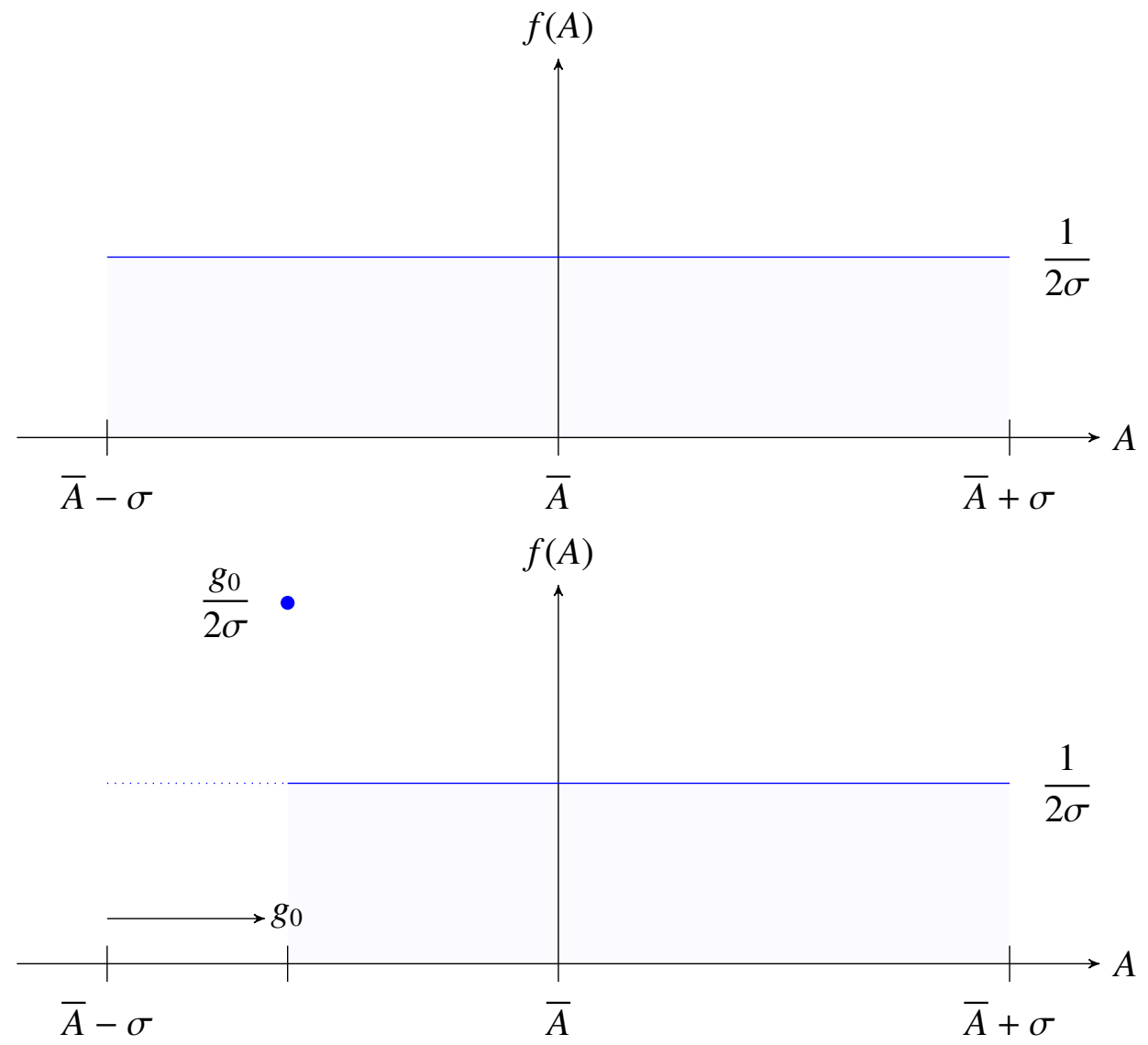

Figure 1.2: Tail Risk Effect of Government Guarantees

Before the realization of $A$, the bank manager must choose the amount of performing assets she needs to report (hereby called $A_{R}$ ) to capital providers. ${ }^{11}$ After $A_{R}$ is reported, $A=A^{\text {actual }}$ is realized and observed by capital providers. Bank managers then "pay" a reporting $\operatorname{cost} C\left(A_{R}, A^{\text {actual }}\right)$ which "punishes" the bank manager for her imprecision and accounting aggressiveness.

Definition 1.1: A reporting cost function $C\left(A_{R}, A^{\text {actual }}\right)$ punishes the manager for imprecision if $C\left(A_{R}^{(1)}, A^{\text {actual }}\right)>C\left(A_{R}^{(2)}, A^{\text {actual }}\right), \forall A_{R}^{(1)}<A_{R}^{(2)}<A^{\text {actual }}$ and

\footnotetext{
${ }^{11}$ Reporting the expected amount of performing assets on a future date is equivalent to providing capital market participants with an estimate of the bank's nonperforming assets in the future, which assembles the bank's loan loss provisioning.
} 
$C\left(A_{R}^{(1)}, A^{\text {actual }}\right)>C\left(A_{R}^{(2)}, A^{\text {actual }}\right), \forall A_{R}^{(1)}>A_{R}^{(2)}>A^{\text {actual }}$.

Definition 1.2: A reporting cost function $C\left(A_{R}, A^{\text {actual }}\right)$ punishes the manager for accounting aggressiveness if $C\left(A_{R}^{(1)}, A^{\text {actual }}\right)<C\left(A_{R}^{(2)}, A^{\text {actual }}\right), \forall A_{R}^{(1)}<A^{\text {actual }}<$ $A_{R}^{(2)}$ such that $A^{\text {actual }}-A_{R}^{(1)}=A_{R}^{(2)}-A^{\text {actual }}>0$.

For the sake of analytical tractability I propose the following piecewise linear reporting cost function $C\left(A_{R}, A^{\text {actual }}\right)$ described by

$$
C\left(A_{R}, A^{\text {actual }}\right)= \begin{cases}\gamma_{1}\left(A^{\text {actual }}-A_{R}\right) & \text { for } A^{\text {actual }} \geq A_{R}, \\ \gamma_{2}\left(A_{R}-A^{\text {actual }}\right) & \text { for } A^{\text {actual }}<A_{R} .\end{cases}
$$

where $\gamma_{1}<\gamma_{2}$.

It is straightforward to see that $C\left(A_{R}, A^{a c t u a l}\right)$ satisfies the conditions of punishing for both imprecision and accounting aggressiveness.

Result 1.2.1 Before the realization of $A_{\text {actual, }}$, the common expectation of the bank manager and capital providers for the terminal value of the bank's assets is given by $E\left[A \mid g_{0}\right]=\bar{A}+\frac{g_{0}^{2}}{4 \sigma}$

Proof. The result is straightforward. In the presence of government guarantees $g_{0}$ the expected terminal value of $A$ becomes $E\left[A \mid g_{0}\right]=$ $\left(\frac{\bar{A}+\sigma+\bar{A}-\sigma+g_{0}}{2}\right)\left(\frac{2 \sigma-g_{0}}{2 \sigma}\right)+\left(\bar{A}-\sigma+g_{0}\right)\left(\frac{g_{0}}{2 \sigma}\right)$. Basic algebraic operations lead to the final expression.

The bank manager's reporting objective is to minimize the expected reporting cost by choosing an optimal reported value of performing assets $A_{R *}$ that 
solves

$$
\underset{A_{R} \in[\bar{A}-\sigma ; \bar{A}+\sigma]}{\operatorname{minimize}} E\left[C\left(A_{R}, A\right)\right]
$$

Result 1.2.2 The optimal reporting choice $A_{R *}$ of the bank's manager is given by $A_{R *}=$ $\bar{A}+\frac{\gamma_{1}-\gamma_{2}}{\gamma_{1}+\gamma_{2}} \sigma+\frac{2 \gamma_{2}}{\gamma_{1}+\gamma_{2}} g_{0}$

Proof. The expression of $E\left[C\left(A_{R}, A\right)\right]$ is solved by the bank manager by integrating $C\left(A_{R}, A\right)$ over all possible realizations of the random variable $A$, including the mass probability on $A=\bar{A}-\sigma+g_{0}$. In other words, the manager solves

$$
\begin{aligned}
E\left[C\left(A_{R}, A\right)\right] & =\int_{A_{R}}^{\bar{A}+\sigma} \gamma_{1}\left(A-A_{R}\right) \frac{1}{2 \sigma} d A+\int_{\bar{A}-\sigma+g_{0}}^{A_{R}} \gamma_{2}\left(A_{R}-A\right) \frac{1}{2 \sigma} d A+ \\
& +\gamma_{2}\left(\bar{A}-\sigma+g_{0}-A_{R}\right) \frac{g_{0}}{2 \sigma}
\end{aligned}
$$

Simple algebraic operations lead to a quadratic polynomial equation on $A_{R}$ whose $A_{R}^{2}$ term is $\frac{\gamma_{1}+\gamma_{2}}{4 \sigma}$ and $A_{R}$ term is $\frac{-\gamma_{1}(\bar{A}+\sigma)-\gamma_{2} \bar{A}+\gamma_{2} \sigma-2 \gamma_{2} g_{0}}{2 \sigma}$. Being $A_{R}$ strictly positive, one can affirm the function has a minimum and it is found at $A_{R *}=\bar{A}+\frac{\gamma_{1}-\gamma_{2}}{\gamma_{1}+\gamma_{2}} \sigma+\frac{2 \gamma_{2}}{\gamma_{1}+\gamma_{2}} g_{0}$.

The expression of $A_{R *}$ shows that even in the absence of government guarantees $\left(g_{0}=0\right.$, therefore $\left.E[A]=\bar{A}\right)$ the bank manager tends to conservatively report $A_{R *}=\bar{A}+\frac{\gamma_{1}-\gamma_{2}}{\gamma_{1}+\gamma_{2}} \sigma<\bar{A}=E[A]$ because of the asymmetric cost of reporting imprecision (since $\left.\gamma_{1}-\gamma_{2}<0\right)$.

For the general case one can define the amount of over-reporting of performing assets (or under-reporting of nonperforming assets) by subtracting $A_{R *}-E\left[A \mid g_{0}\right]$. This leads to the following expression:

$$
A_{R *}-E\left[A \mid g_{0}\right]=\frac{\gamma_{1}-\gamma_{2}}{\gamma_{1}+\gamma_{2}} \sigma+\left(\frac{2 \gamma_{2}}{\gamma_{1}+\gamma_{2}} g_{0}-\frac{g_{0}^{2}}{4 \sigma}\right)
$$


The negative term $\frac{\gamma_{1}-\gamma_{2}}{\gamma_{1}+\gamma_{2}} \sigma$ reflects the over-provisioning that is purely due to the risk profile of the bank's assets (which depends on the individual bank and the business cycle). Analyzing the second term $\frac{2 \gamma_{2}}{\gamma_{1}+\gamma_{2}} g_{0}-\frac{g_{0}^{2}}{4 \sigma}$ one can conclude that it is a quadratic equation with zeros at $g_{0}^{(1)}=0$ and $g_{0}^{(2)}=\frac{8 \gamma_{2} \sigma}{\gamma_{1}+\gamma_{2}}$. Because parameter $g_{0} \in\left[\begin{array}{ll}0 & 2 \sigma\end{array}\right]$ and $\gamma_{2}>\gamma_{1}>0$, the second polynomial root is such that $4 \sigma<g_{0}^{(2)}<8 \sigma$, meaning that $\frac{2 \gamma_{2}}{\gamma_{1}+\gamma_{2}} g_{0}-\frac{g_{0}^{2}}{4 \sigma} \geq 0$ for all $g_{0} \in\left[\begin{array}{ll}0 & 2 \sigma\end{array}\right]$. Differently put, this term is always positive, representing a component of under-provisioning which is stronger the greater $g_{0}$ and $\gamma_{2}-\gamma_{1}$ are.

\subsubsection{Hypotheses Development}

Based on the results of the analytical framework, I state the main hypothesis of this paper in a directional form:

Hypothesis 1 Larger fiscal deficits are associated with greater levels of loan loss provisions reported by banks.

This prediction is not, however, without tension. While hypothesis H1 can be described as a positive association between the country's fiscal deficit and banks' reporting incentives (i.e., an interaction of real and financial reporting effects), the literature documents different theoretical and empirical associations which could lead to opposite predictions. Figure 1.3 depicts how the hypothesis of a positive association (H1) competes with two alternative effects (red-shaded blocks). ${ }^{12}$

\footnotetext{
${ }^{12}$ Figure 1.3 also illustrates how fiscal deficits may affect managers' assessment of credit risk through indirect channels of actual and expected effects on business cycles (blue-shaded)
} 
The second (middle) path in this directed acyclic graph can be labeled as the bank security pricing effect. Deteriorating fiscal deficits would weaken government guarantees (Acharya et al., 2014; Correa et al., 2014) and negatively affect bank security prices (O'Hara and Shaw, 1990; Gandhi and Lustig, 2015, Correa et al. 2014; Gandhi et al., 2016). As bank securities go down, bankers' incentives to over-provision (as in Beaver et al., 1989: Beaver and Engel, 1996) are reduced, leading to less provisioning (an overall negative association between fiscal deficit and loan loss provision).

The third (lower) path can be seen as a "banks' risk-taking" effect. Deteriorating fiscal deficits would weaken government guarantees, leading to less risk taking (Stern and Feldman, 2004: Gropp et al., 2013; Fischer et al., 2014). The direct economic consequence of banks allocating capital to less risky assets would be lower levels of loan loss provision (negative association between deficits and provisioning, as also suggested by the second path). While the links connecting the constructs for the second and third path are well documented by the literature, the reporting effect described by $\mathrm{H} 1$ is unexplored and would predict the opposite effect.

Since the direct channel hypothesized operates through the strength of the fiscal backing the government can provide the banks, I predict that this effect is not only influenced by the country's deficit in a given year but also by the "snapshot" of the government's indebtedness. ${ }^{13}$ For instance, higher levels of indebtedness would affect the government's capability to access borrowing markets and, consequently, sustain larger deficits in the future. Simply put, a given level

\footnotetext{
${ }^{13}$ Although consistent with direct channel effects, the hypothesis of the effect of deficits on banks' loan loss provisions being amplified by indebtedness is also consistent with expected indirect channel effects, in particular the government's ability to use fiscal policy to produce future effects on business cycles.
} 
of fiscal deficit will have a stronger effect on the strength and reliability of government guarantees the higher the country's debt-to-GDP ratio is. This leads to the second hypothesis, also stated in directional (amplification effect) form:

Hypothesis 2 The association between fiscal deficits and banks' loan loss provisions is stronger for higher debt-to-GDP ratios (country-specific stock variable).

In the following section I present the empirical analyses conducted to test both hypotheses, and their corresponding results. 


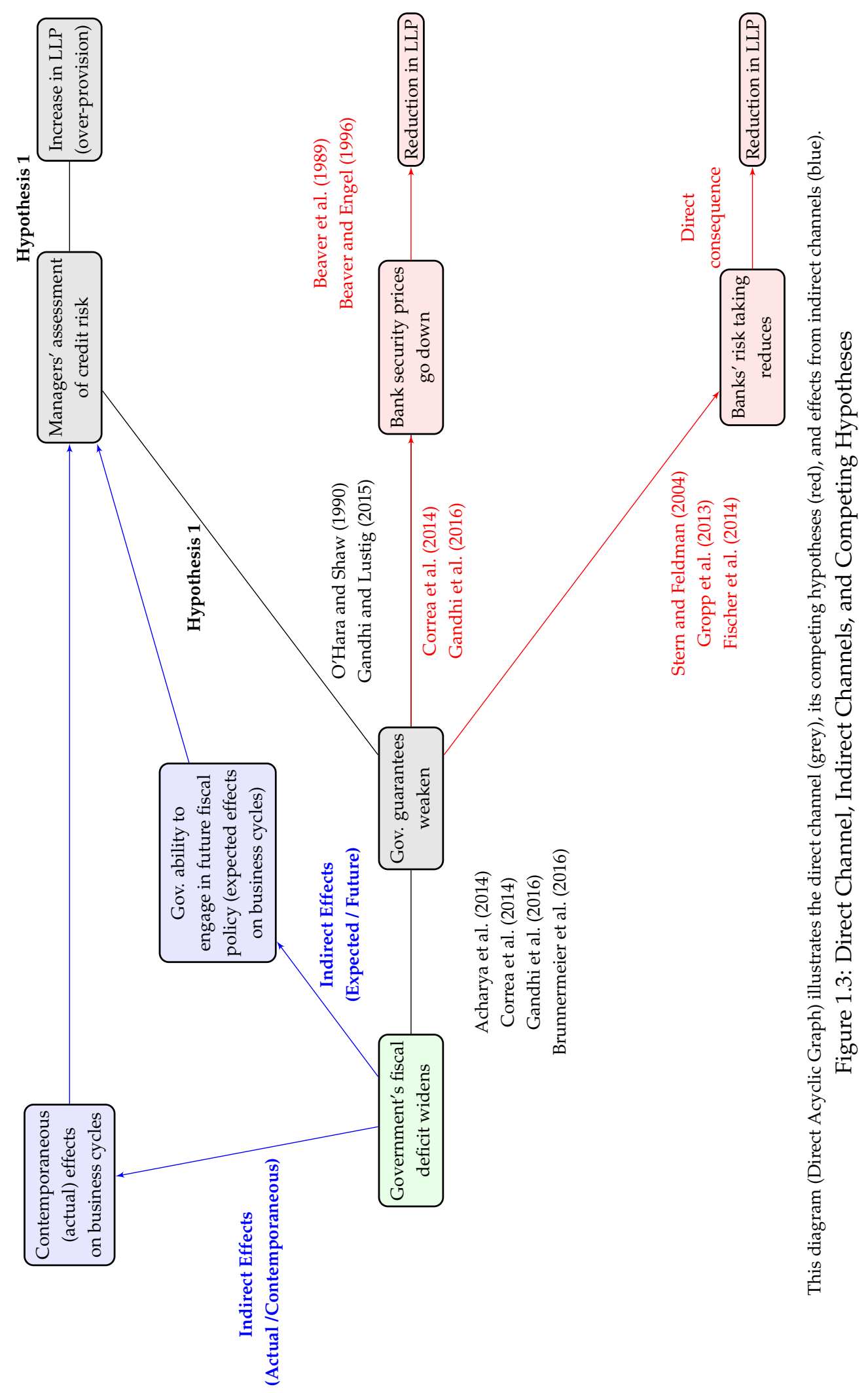




\subsection{Empirical Results}

\subsubsection{Data Description and Sample Selection}

A voluminous literature studies the determinants of banks' loan loss provisions by reduced-form expressions including bank-specific and macroeconomic controls (see Beatty and Liao, 2014, for a survey on the most commonly used covariates). Generally speaking, this is represented by the following equation (1.3),

$$
l l p_{i, t}=\Gamma \cdot M_{c, t}+\Lambda \cdot X_{i, t}+\epsilon_{i, t}
$$

where $X_{i, t}=\left(\begin{array}{lll}x_{i, t}^{(1)} & x_{i, t}^{(2)} \ldots x_{i, t}^{\left(N_{B}\right)}\end{array}\right)$ is a vector of $N_{B}$ bank-specific economic covariates and $M_{i, t}=\left(m_{c, t}^{(1)} m_{c, t}^{(2)} \ldots m_{c, t}^{\left(N_{M}\right)}\right)$ is a vector of $N_{M}$ country-specific macroeconomic variables. As the objective of my work is to study the dependence of banks' provisioning on both business cycles and governments' deficits (fiscal policy effect), there must be at least one empirical proxy for each of these two constructs.

My main proxy for business cycle is the country's percent variation of GDP Per Capita $\left(\% \Delta\right.$ PerCapitaGDP $\left.P_{c, t}\right)$ from year $t-1$ to $t .{ }^{14}$ For government deficits, I compute Deficit $t_{c, t}$ by taking central governments' expenditures minus revenues, normalized by the respective country's GDP. ${ }^{15}$

I collect data from multiple sources, including public and private databases.

\footnotetext{
${ }^{14}$ Variations in GDP and GDP per capita are often considered in the literature (Beatty and Liao . 2014). Apart from country-years of abnormal population growth, aggregate and per capita measures are strongly correlated. For international settings where banks headquartered in emerging markets comprise a relevant fraction of the sample, per capita measures are more suitable to ensure the proxy controls for variation in economic output driven by population growth.

${ }^{15}$ I define "deficit" as expenditures "minus" revenues, so that a positive (negative) deficit is a deficit (surplus). This choice is consistent with the fact that most countries run a deficit, not a surplus. Moreover, it makes the effects of deficit $\left(\right.$ Deficit $\left._{c, t}\right)$ and indebtedness $\left(\right.$ DebttoGDP $\left._{c, t}\right)$ directionally consistent - i.e., higher values of deficit and indebtedness are associated with deteriorating fiscal conditions.
} 
I obtain $\% \triangle$ PerCapitaGDP $P_{c, t}$ from the World Bank's database and Deficit $t_{c, t}$ from the IMF Cross Country Macroeconomic Statistics database. I then start my sample construction by identifying countries where time series of both $\% \triangle$ PerCapitaGDP $P_{c, t}$ and Deficit $c_{c, t}$ are available with at least 15 years of observations. For each of these countries I merge the macroeconomic data with bankspecific accounting variables obtained from Bankscope.

Building upon Beatty and Liao (2011), and Bushman and Williams (2012. 2015), I consider as the main set of bank-specific covariates $X_{i, t}$ a vector including Ebllp $p_{i, t}$ (earnings before loan loss provision and taxes, normalized by lagged total loans), $C A P_{i, t-1}$ (capital structure control, proxied by the bank's total equity divided by total assets), Size $_{i, t-1}$ (the natural logarithm of the bank's total assets measured in millions of USD) and the forward-looking, contemporaneous and two-lagged terms of the variation on nonperforming loans normalized by lagged total assets $\left(\triangle N P L_{i, t+1}, \triangle N P L_{i, t}, \triangle N P L_{i, t-1}\right.$, and $\left.\triangle N P L_{i, t-2}\right)$. The inclusion of Ebllp $_{i, t}$ controls for potential incentives bank managers may have to discretionarily report loan loss provisions in order to shift income across reporting periods (see Greenawalt and Sinkey, 1988; Beatty et al., 1995; Collins et al. 1995; Laeven and Majnoni, 2003; Bikker and Metzemakers, 2005; Liu and Ryan, 2006; Fonseca and González, 2008; Pérez et al., 2008; Gebhardt and NovotnyFarkas, 2011; Kilic et al., 2012, Bushman and Williams, 2012, 2015). Sequential terms of $\triangle N P L_{i, t+1}, \triangle N P L_{i, t}, \triangle N P L_{i, t-1}$, and $\triangle N P L_{i, t-2}$ control for the actual creditworthiness of the bank's loan portfolio, including the forward-looking term $\triangle N P L_{i, t+1}$ as a measure of the timeliness of banks' loan loss provisions to incorporate future nonperforming loans (Bushman and Williams, 2012, 2015). Size $e_{i, t-1}$ and $C A P_{i, t-1}$ are respectively included to account for the differential regulatory scrutiny large banks are subject to and the potential effect of the bank's capital 
ratio.

I compute the terms comprised by vector $X_{i, t}$ for the period ranging from 1996 to 2014 . I then require that each bank-year observation must have valid data for the macroeconomic variables $\% \Delta$ PerCapitaGDP $P_{c, t}$ and Deficit ${ }_{c, t}$ of the country in which the bank is headquartered. I also exclude observations whose total assets are less than 2 billion USD, ${ }^{16}$ exclude investment banks and require at least three consecutive years of data for a bank to be included in the sample. Last, I require the bank fundamentals data necessary for estimating the model proposed by Bushman and Williams (2012, 2015) to be valid and jointly trimmed at the 1\% and 99\% levels. Table 1.1 depicts the sequential filters I apply to obtain my final sample. Table 1.2 reports how the final sample of 18,800 valid bank-year observations is distributed across 47 different countries. This represents the main (and largest) sample to be used in my empirical analyses. Tables 1.3 and 1.4 respectively report the summary statistics of bank-specific and macroeconomic covariates and their correlation matrix.

\footnotetext{
${ }^{16}$ Prior research suggests censoring the data based on a minimum threshold of assets because small banks are more subject to financial misreporting and restatements. My results are robust to different thresholds of minimum total assets.
} 
Table 1.1: Sample Selection — Sequential Filters

\begin{tabular}{lc}
\hline Sequential Filters & Count \\
\hline All 47 countries from 1996-2014 & 291,376 \\
Jointly requiring data of Deficit $t_{c, t}$ and \% $\Delta$ PerCapitaGDP $P_{c, t}$ & 276,308 \\
Excluding observations with less than 2 billion USD of Total Assets & 53,425 \\
Excluding Investment Banks & 50,309 \\
Requiring at least 3 consecutive years of observations & 43,994 \\
Requiring data to compute the model proposed by Bushman and Williams & 2012 \\
Trimming the fundamentals ratios at the 1\% and 99\% levels & 2015 \\
\hline
\end{tabular}


Table 1.2: Sample Description by Country

\begin{tabular}{|c|c|c|c|c|c|c|c|}
\hline Country Name & Count & Perc. & Cum. & Country Name & Count & Perc. & Cum. \\
\hline Australia & 180 & 0.96 & 0.96 & Morocco & 18 & 0.1 & 41.79 \\
\hline Austria & 44 & 0.23 & 1.19 & Netherlands & 42 & 0.22 & 42.01 \\
\hline Bangladesh & 24 & 0.13 & 1.32 & New Zealand & 84 & 0.45 & 42.46 \\
\hline Belgium & 20 & 0.11 & 1.43 & Nigeria & 74 & 0.39 & 42.85 \\
\hline Brazil & 338 & 1.8 & 3.22 & Norway & 306 & 1.63 & 44.48 \\
\hline Canada & 175 & 0.93 & 4.15 & Pakistan & 137 & 0.73 & 45.21 \\
\hline Chile & 214 & 1.14 & 5.29 & Peru & 111 & 0.59 & 45.8 \\
\hline Colombia & 104 & 0.55 & 5.85 & Philippines & 137 & 0.73 & 46.53 \\
\hline Denmark & 122 & 0.65 & 6.49 & Poland & 130 & 0.69 & 47.22 \\
\hline Finland & 59 & 0.31 & 6.81 & Portugal & 198 & 1.05 & 48.27 \\
\hline France & 505 & 2.69 & 9.49 & Qatar & 29 & 0.15 & 48.43 \\
\hline Germany & 36 & 0.19 & 9.69 & Romania & 35 & 0.19 & 48.61 \\
\hline Greece & 31 & 0.16 & 9.85 & Russian Federation & 283 & 1.51 & 50.12 \\
\hline Hungary & 59 & 0.31 & 10.16 & Singapore & 50 & 0.27 & 50.38 \\
\hline India & 496 & 2.64 & 12.8 & South Africa & 109 & 0.58 & 50.96 \\
\hline Indonesia & 38 & 0.2 & 13.01 & Spain & 459 & 2.44 & 53.4 \\
\hline Ireland & 50 & 0.27 & 13.27 & Sweden & 104 & 0.55 & 53.96 \\
\hline Italy & 1,317 & 7.01 & 20.28 & Switzerland & 218 & 1.16 & 55.12 \\
\hline Japan & 3,391 & 18.04 & 38.31 & Thailand & 239 & 1.27 & 56.39 \\
\hline Jordan & 60 & 0.32 & 38.63 & Trinidad and Tobago & 36 & 0.19 & 56.58 \\
\hline Kenya & 21 & 0.11 & 38.74 & Turkey & 200 & 1.06 & 57.64 \\
\hline Lebanon & 110 & 0.59 & 39.33 & United Kingdom & 216 & 1.15 & 58.79 \\
\hline Malaysia & 406 & 2.16 & 41.49 & United States & 7,747 & 41.21 & 100 \\
\hline \multirow[t]{2}{*}{ Mexico } & 38 & 0.2 & 41.69 & & & & \\
\hline & & & & Total & 18,800 & 100 & 100 \\
\hline
\end{tabular}


Table 1.3: Summary Statistics — Bank-specific and Macroeconomic Variables

\begin{tabular}{lrrrrrr}
\hline & N Obs & Mean & Std. & $25 \%$ & $50 \%$ & $75 \%$ \\
\hline ll $p_{i, t}$ & 18,800 & 0.0092114 & 0.0131834 & 0.0021513 & 0.0052013 & 0.0109263 \\
Ebll $_{i, t}$ & 18,800 & 0.0323415 & 0.0372117 & 0.0128009 & 0.025337 & 0.0394534 \\
$\Delta N P L_{i, t+1}$ & 18,800 & 0.0021598 & 0.016338 & -0.0017986 & 0.0001465 & 0.0034019 \\
$\Delta N P L_{i, t}$ & 18,800 & 0.0018488 & 0.0101993 & -0.0017255 & 0.000256 & 0.0036006 \\
$\Delta N P L_{i, t-1}$ & 18,800 & 0.0025617 & 0.0714688 & -0.0017786 & 0.0002612 & 0.0035427 \\
$\Delta N P L_{i, t-2}$ & 18,800 & -0.0039025 & 0.8337379 & -0.0018019 & 0.0002538 & 0.0033929 \\
CAP $_{i, t-1}$ & 18,800 & 0.0837767 & 0.0438719 & 0.05759 & 0.0781725 & 0.10010 \\
Size $_{i, t-1}$ & 18,800 & 9.115008 & 1.205028 & 8.097462 & 8.904819 & 9.945133 \\
\% $_{\text {PerCapitaGDP }}$ & 18,800 & .0449375 & 0.0863914 & 0.007072 & 0.0384778 & .0567369 \\
Deficit $_{c, t}$ & 18,800 & 0.0320958 & 0.0438017 & 0.0104646 & 0.032319 & 0.0672965 \\
\hline
\end{tabular}


Table 1.4: Summary Statistics — Correlation Matrix

\begin{tabular}{|c|c|c|c|c|c|c|c|c|c|}
\hline & $\cong$ & 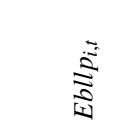 & 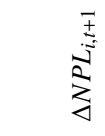 & 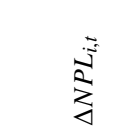 & $\begin{array}{l}\bar{I} \\
\vdots \\
\vdots \\
\vdots \\
\vdots\end{array}$ & 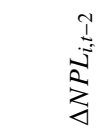 & $\underset{0}{\underline{z}}$ & 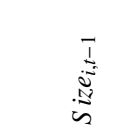 & 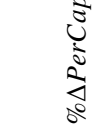 \\
\hline Ebllp $_{i, t}$ & 0.3275 & & & & & & & & \\
\hline$\triangle N P L_{i, t+1}$ & 0.0876 & 0.0396 & & & & & & & \\
\hline$\Delta N P L_{i, t}$ & 0.3168 & 0.0363 & 0.2171 & & & & & & \\
\hline$\triangle N P L_{i, t-1}$ & 0.0523 & 0.0124 & -0.0491 & 0.0581 & & & & & \\
\hline$\Delta N P L_{i, t-2}$ & -0.0085 & -0.003 & 0.0019 & 0.0089 & 0.0015 & & & & \\
\hline$C A P_{i, t-1}$ & 0.1689 & 0.3084 & 0.0615 & 0.0884 & 0.0197 & 0.0014 & & & \\
\hline Size $_{i, t-1}$ & -0.0167 & -0.0636 & -0.0307 & -0.045 & -0.0134 & 0.0035 & -0.1511 & & \\
\hline$\% \Delta$ PerCapitaGDP $P_{c, t}$ & 0.0142 & 0.1913 & 0.0051 & -0.0943 & -0.007 & 0.0031 & 0.0807 & -0.0555 & \\
\hline Deficit $_{c, t}$ & 0.0629 & -0.1774 & -0.0467 & 0.0759 & 0.0284 & -0.0008 & -0.0542 & 0.0383 & -0.2853 \\
\hline
\end{tabular}

\subsubsection{Fiscal Policy, Business Cycle and Loan Loss Provision}

I start testing the hypothesis of a positive association between Deficit $t_{c, t}$ and $l l p_{i, t}$ by estimating variants of equation (1.3). In addition to the bank-specific covariates $X_{i, t}=\left(\right.$ Ebllp $\left._{i, t}, \Delta N P L_{i, t+1}, \Delta N P L_{i, t}, \Delta N P L_{i, t-1}, \Delta N P L_{i, t-2}, C A P_{i, t-1}, S i z e_{i, t}\right)$, and the macroeconomic covariates $M_{i, t}=\left(\% \Delta\right.$ PerCapitaGDP $P_{c, t}$, Deficit $\left.t_{c, t}\right), \mathrm{I}$ include in the last specification the interactions of the business cycle and deficit with the forward-looking term $\triangle N P L_{i, t+1}$ - i.e., $\triangle N P L_{i, t+1} \times \% \triangle P$ erCapitaGDP $P_{c, t}$ and $\triangle N P L_{i, t+1} \times$ Deficit $_{c, t}$, to empirically test whether business cycles and fiscal policy also affect the timeliness of the loan loss provision. This leads to the 
following augmented model described by equation (1.4).

$$
\begin{aligned}
\text { llp }_{i, t}= & \alpha+\gamma_{1} \times \% \Delta \text { PerCapitaGDP } \\
& +\gamma_{c, t} \times \gamma_{2} \times \text { Deficit }_{c, t}+ \\
& +\lambda_{1} \times \text { Ebllp }_{i, t, j}+\lambda_{2} \times \Delta N P \text { PerCapitaGDP }_{c, t}+\gamma_{4} \times \Delta N P L_{i, t+1}+\lambda_{3} \times \Delta N P L_{i, t}+\lambda_{4} \times \Delta N P L_{i, t-1}+ \\
& +\lambda_{5} \times \Delta N P L_{i, t-2}+\lambda_{6} \times C A P_{i, t-1}+\lambda_{7} \times \text { Size }_{i, t-1}+ \\
& +\epsilon_{i, t}
\end{aligned}
$$

My main coefficients of interest are the estimates of $\gamma_{1}$ and $\gamma_{2}$. I cluster all standard errors at the country level and include country, year, and bank-type fixed effects in all specifications. Coefficient estimates are reported in Table 1.5.

My pooled results support the hypothesis that banks' loan loss provisions co-move negatively with business cycles and positively with governments' deficits. In all four empirical specifications the OLS estimates of the coefficients $\gamma_{1}$ and $\gamma_{2}$ are, respectively, negative and positive, and statistically significant (p-values less than 1\% and 5\% for all coefficient estimates of Deficit $t_{c, t}$ and $\% \Delta$ PerCapitaGDP ${ }_{c, t}$, respectively). Surprisingly, in terms of economic significance, my estimates suggest that governments' deficits play a more important role in banks' provisioning for loan losses than the macroeconomic proxy for business cycle. While a one standard deviation increase in $\% \Delta$ PerCapitaGDP $P_{c, t}$ is on average associated with a $8.36 \%$ standard deviation decrease in the dependent variable $l l p_{i, t}$, a one standard deviation increase in Deficit $t_{c, t}$ has an average effect of a $25.71 \%$ standard deviation increase in $l l p_{i, t} .{ }^{17}$

\footnotetext{
${ }^{17}$ Economic magnitudes in this setting should be interpreted with caution. While empirical results suggest that Deficit $_{c, t}$ represents a macroeconomic variable that is more informative than (the other macroeconomic variable) $\% \triangle$ PerCapitaGDP $P_{c, t}$, we cannot say deficits are more relevant than business cycles in general because bank-specific covariates are also a function of the aggregate level of economic activity.
} 
The statistically insignificant estimates of $\gamma_{3}$ and $\gamma_{4}$ fail to provide evidence that, overall, business cycles and fiscal policy affect the timeliness (forwardlooking) characteristic of the $l l p_{i, t}$.

While the results of Table 1.5 are consistent with the hypothesis of fiscal deficits playing an important role in banks' financial reporting, a natural concern that can be raised is whether these pooled results are driven by a particular small subset of countries with particular features in their banking sectors or political economy. To provide further evidence of how the results of Table 1.5 are generalizable to different subsamples of banks, I partition my sample based on 7 geographic groups - (1) English-speaking North America (the United States and Canada); (2) Latin America and the Caribbean (Brazil, Chile, Colombia, Mexico, Peru, and Trinidad and Tobago); (3) Asia/Pacific Developed (Australia, Japan, New Zealand, and Singapore); (4) Asia/Pacific Emerging (Bangladesh, India, Indonesia, Malaysia, Pakistan, Philippines, Russian Federation, and Thailand) (5) Western Europe (Austria, Belgium, Denmark, Finland, France, Germany, Ireland, Italy, the Netherlands, Norway, Portugal, Spain, Sweden, Switzerland, and the United Kingdom) (6) Eastern Europe (Greece, Hungary, Poland, and Romania); (7) the Middle East \& Africa (Jordan, Kenya, Lebanon, Morocco, Nigeria, Qatar, South Africa, and Turkey) - then I re-estimate the empirical specification including both $\% \triangle P e r C a p i t a G D P_{c, t}$ and Deficit $t_{c, t}$ for each geographic subsample. Results are presented in Table 1.6.

My coefficient estimates of Deficit $t_{c, t}$ are positive and statistically significant for all seven geographies (p-values ranging from $7 \%$ for the US and Canada set to $1.7 \%$ for Western Europe and $0.01 \%$ for Latin America and the Caribbean), providing supporting evidence on the generalizability of the fis- 
cal policy channel. Conversely, estimates of the business cycle comovement $\left(\% \triangle\right.$ PerCapitaGDP $\left.P_{c, t}\right)$ are, at best, mixed (statistically insignificant for four subsamples; significantly negative for Eastern Europe and the Middle East \& Africa and, surprisingly, significantly positive for the US and Canada).

Since the hypothesized mechanism that leads to the positive association between banks' provisioning and the governments' deficit is derived from the effect of fiscal policy on the strength of government guarantees (direct channel) together with the financial reporting incentives banks have in place to set up this expense to conservatively reflect credit losses, one should expect this association to be stronger when individual banks' incentives to avoid underprovisioning are stronger, as illustrated by equation (1.2).

Given the empirical challenge of directly assessing a bank-year measure of over-provisioning bias, I construct for each valid $(i, t)$ observation the variable Over $_{i, t}$ as bank $i$ 's reported loan loss provision "minus" the actual charge-offs in year $t$ scaled by total loans. I then create a dummy variable $I_{i, t}^{\text {Over }}$ as

$$
I_{i, t}^{\text {Over }}= \begin{cases}1 & \text { if } \text { Over }_{i, t}>\text { Over }_{i, t-1}>0 \text { and } \text { Over }_{i, t-2}>0, \\ 0 & \text { otherwise }\end{cases}
$$

and include in my main specification of equation (1.4) the lagged term $I_{i, t-1}^{\text {Over }}$ and its interactions with $\% \Delta$ PerCapitaGDP $P_{c, t}$ and Deficit $c_{c, t}$. These reduced-form estimates allow me to control for heterogeneous effects coming from banks which have been through an increasing trend of over-provisioning. Coefficient estimates are reported in Table 1.7.

Statistically significant (positive) coefficient estimates of $I_{i, t-1}^{\text {Over }}$ in all specifications suggest that banks with past over-provisioning behavior (from $t-3$ to 
$t-1$ ) also tend to over-provision at time $t$, which is consistent with a strong time-invariant component determining financial reporting incentives of reporting $l l p_{i, t}$. Estimates of the interaction effect with fiscal policy (i.e., $I_{i, t-1}^{\text {Over }} \times D e f i c i t_{c, t}$ ) are positive and statistically significant ( $\mathrm{p}$-values less than $1 \%$ in specifications (3) and (4)), which provides evidence consistent with the association between Deficit $c_{, t}$ and $l l p_{i, t}$ being stronger for banks with stronger incentives to overprovision. Nevertheless, the stronger statistical association for this subset of banks does not subsume the unconditional fiscal effect reflected by the positive coefficients of Deficit $t_{c, t}$ (all significant, with p-values of less than 1\%). Estimates of $I_{i, t-1}^{\text {Over }} \times$ PerCapitaGDP $P_{c, t}$, however, are all statistically insignificant. 
Table 1.5: Fiscal Policy and Business Cycles — Main Result

\begin{tabular}{|c|c|c|c|c|c|}
\hline & \multicolumn{5}{|c|}{ Dep. variable $=l l p_{i, t}$} \\
\hline & (1) & (2) & (3) & $(4)$ & (5) \\
\hline \multirow[t]{2}{*}{$\% \Delta$ PerCapitaGDP $P_{c, t}$} & & $-0.0164 * * *$ & & $-0.0128 * *$ & $-0.0132 * *$ \\
\hline & & $(0.0056)$ & & $(0.0056)$ & $(0.0056)$ \\
\hline \multirow[t]{2}{*}{ Deficit $_{c, t}$} & & & $0.0844 * * *$ & $0.0774 * * *$ & $0.0793 * * *$ \\
\hline & & & $(0.0216)$ & $(0.0224)$ & $(0.0219)$ \\
\hline \multirow[t]{2}{*}{$\Delta N P L_{i, t+1} \times \% \Delta$ PerCapitaGDP $P_{c, t}$} & & & & & 0.1942 \\
\hline & & & & & $(0.2081)$ \\
\hline \multirow[t]{2}{*}{$\Delta N P L_{i, t+1} \times$ Deficit $_{c, t}$} & & & & & -0.6234 \\
\hline & & & & & $(0.4602)$ \\
\hline \multirow[t]{2}{*}{ Ebllp $_{i, t}$} & $0.0767 * * *$ & $0.0764 * * *$ & $0.0776 * * *$ & $0.0773 * * *$ & $0.0769 * * *$ \\
\hline & $(0.0149)$ & $(0.0151)$ & $(0.0150)$ & $(0.0151)$ & $(0.0154)$ \\
\hline \multirow[t]{2}{*}{$\Delta N P L_{i, t+1}$} & -0.0102 & -0.0124 & -0.0028 & -0.0052 & -0.0167 \\
\hline & $(0.0243)$ & $(0.0253)$ & $(0.0233)$ & $(0.0241)$ & $(0.0193)$ \\
\hline \multirow[t]{2}{*}{$\Delta N P L_{i, t}$} & $0.2960 * * *$ & $0.2881 * * *$ & $0.2922 * * *$ & $0.2871 * * *$ & $0.2930 * * *$ \\
\hline & $(0.0227)$ & $(0.0240)$ & $(0.0214)$ & $(0.0233)$ & $(0.0241)$ \\
\hline \multirow[t]{2}{*}{$\Delta N P L_{i, t-1}$} & 0.0040 & 0.0038 & 0.0037 & 0.0036 & 0.0027 \\
\hline & $(0.0034)$ & $(0.0033)$ & $(0.0032)$ & $(0.0032)$ & $(0.0035)$ \\
\hline \multirow[t]{2}{*}{$\Delta N P L_{i, t-2}$} & $-0.0002 * * *$ & $-0.0002 * * *$ & $-0.0002 * * *$ & $-0.0001 * * *$ & $-0.0001 * * *$ \\
\hline & $(0.0000)$ & $(0.0000)$ & $(0.0000)$ & $(0.0000)$ & $(0.0000)$ \\
\hline \multirow[t]{2}{*}{$C A P_{i, t-1}$} & 0.0111 & 0.0115 & 0.0111 & 0.0114 & 0.0114 \\
\hline & $(0.0076)$ & $(0.0075)$ & $(0.0074)$ & $(0.0073)$ & $(0.0072)$ \\
\hline \multirow[t]{2}{*}{ Size $_{i, t-1}$} & 0.0002 & 0.0002 & 0.0003 & 0.0002 & 0.0003 \\
\hline & $(0.0004)$ & $(0.0004)$ & $(0.0004)$ & $(0.0004)$ & $(0.0004)$ \\
\hline Observations & 18,800 & 18,800 & 18,800 & 18,800 & 18,800 \\
\hline R-squared & 0.305 & 0.311 & 0.319 & 0.323 & 0.326 \\
\hline Adjusted R-squared & 0.302 & 0.308 & 0.316 & 0.320 & 0.324 \\
\hline
\end{tabular}

This table reports OLS coefficient estimates of different specifications of the model $l l p_{i, t}=\Lambda \cdot X_{i, t}+\gamma_{1} \times$ $\% \Delta$ PerCapitaGDP $P_{c, t}+\gamma_{2} \times$ Deficit $_{c, t}+\gamma_{3} \times \Delta N P L_{i, t+1} \times \% \Delta$ PerCapitaGDP $P_{c, t}+\gamma_{4} \times \Delta N P L_{i, t+1} \times$ Deficit $_{c, t}+$ $\epsilon_{i, t}$ for the whole sample of banks from 47 countries. Regressions include year, country, and bank-type fixed effects. Country level clustered standard errors are reported in parentheses. ${ }^{* * *},{ }^{* *}$, and ${ }^{*}$ indicate statistical significance levels of $p<0.01, p<0.5$, and $p<0.1$, respectively. Variables are described in Appendix A 


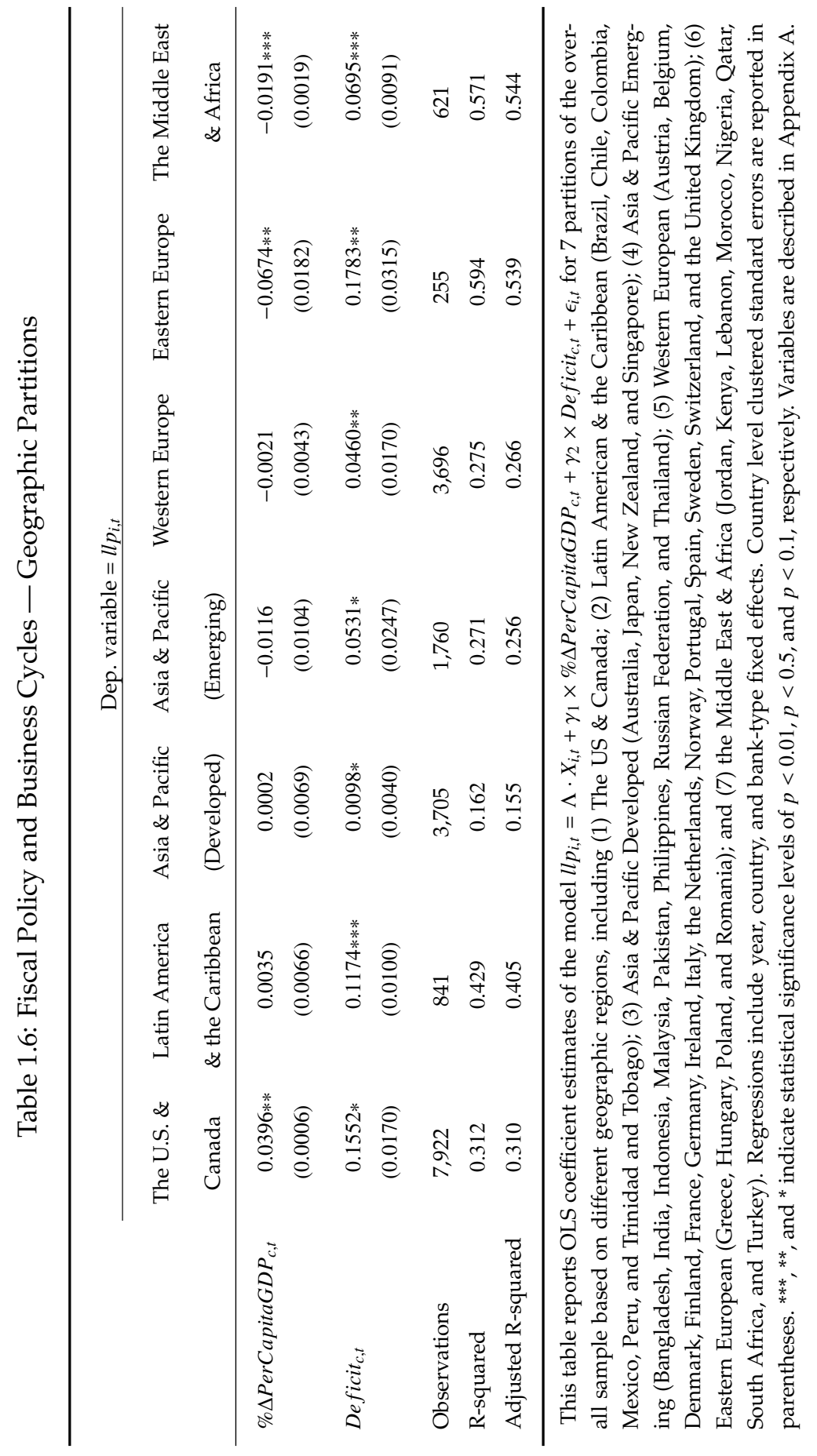


Table 1.7: Fiscal Policy and Business Cycles — Results Interacting with Overprovisioning Behavior

\begin{tabular}{|c|c|c|c|c|}
\hline & \multicolumn{4}{|c|}{ Dep. variable $=l l p_{i, t}$} \\
\hline & $(1)$ & (2) & (3) & (4) \\
\hline$\% \Delta$ PerCapitaGDP $P_{c, t}$ & $\begin{array}{c}-0.0122 * * \\
(0.0055)\end{array}$ & $\begin{array}{c}-0.0127 * * \\
(0.0062)\end{array}$ & $\begin{array}{c}-0.0120 * * \\
(0.0054)\end{array}$ & $\begin{array}{c}-0.0133 * * \\
(0.0061)\end{array}$ \\
\hline Deficit $_{c, t}$ & $\begin{array}{l}0.0786 * * * \\
(0.0234)\end{array}$ & $\begin{array}{l}0.0785 * * * \\
(0.0235)\end{array}$ & $\begin{array}{l}0.0744 * * * \\
(0.0217)\end{array}$ & $\begin{array}{l}0.0733 * * * \\
(0.0218)\end{array}$ \\
\hline$I_{i, t-1}^{O v e r}$ & $\begin{array}{l}0.0023 * * * \\
(0.0004)\end{array}$ & $\begin{array}{l}0.0022 * * * \\
(0.0004)\end{array}$ & $\begin{array}{l}0.0017 * * * \\
(0.0005)\end{array}$ & $\begin{array}{l}0.0014 * * * \\
(0.0005)\end{array}$ \\
\hline$I_{i, t-1}^{\text {Over }} \times$ PerCapitaGDP $P_{c, t}$ & & $\begin{array}{c}0.0018 \\
(0.0047)\end{array}$ & & $\begin{array}{c}0.0050 \\
(0.0044)\end{array}$ \\
\hline$I_{i, t-1}^{\text {Over }} \times$ Deficit $_{c, t}$ & & & $\begin{array}{l}0.0177 * * \\
(0.0081)\end{array}$ & $\begin{array}{l}0.0212 * * * \\
(0.0078)\end{array}$ \\
\hline Ebllp $_{i, t}$ & $\begin{array}{l}0.0776 * * * \\
(0.0153)\end{array}$ & $\begin{array}{l}0.0776 * * * \\
(0.0153)\end{array}$ & $\begin{array}{l}0.0777 \text { *** } \\
(0.0154)\end{array}$ & $\begin{array}{l}0.0778 * * * \\
(0.0153)\end{array}$ \\
\hline$\Delta N P L_{i, t+1}$ & $\begin{array}{r}-0.0066 \\
(0.0244)\end{array}$ & $\begin{array}{r}-0.0065 \\
(0.0245)\end{array}$ & $\begin{array}{r}-0.0066 \\
(0.0241)\end{array}$ & $\begin{array}{r}-0.0062 \\
(0.0242)\end{array}$ \\
\hline$\triangle N P L_{i, t}$ & $\begin{array}{l}0.2783 * * * \\
(0.0224)\end{array}$ & $\begin{array}{l}0.2794 * * * \\
(0.0224)\end{array}$ & $\begin{array}{l}0.2772 * * * \\
(0.0225)\end{array}$ & $\begin{array}{l}0.2773 * * * \\
(0.0224)\end{array}$ \\
\hline$\Delta N P L_{i, t-1}$ & $\begin{array}{c}0.0034 \\
(0.0031)\end{array}$ & $\begin{array}{c}0.0034 \\
(0.0031)\end{array}$ & $\begin{array}{c}0.0035 \\
(0.0031)\end{array}$ & $\begin{array}{c}0.0034 \\
(0.0030)\end{array}$ \\
\hline$\Delta N P L_{i, t-2}$ & $\begin{array}{c}-0.0002 * * * \\
(0.0000)\end{array}$ & $\begin{array}{c}-0.0001 * * * \\
(0.0000)\end{array}$ & $\begin{array}{c}-0.0002 * * * \\
(0.0000)\end{array}$ & $\begin{array}{c}-0.0001 * * * \\
(0.0000)\end{array}$ \\
\hline$C A P_{i, t-1}$ & $\begin{array}{c}0.0120 \\
(0.0074)\end{array}$ & $\begin{array}{c}0.0119 \\
(0.0075)\end{array}$ & $\begin{array}{c}0.0121 \\
(0.0075)\end{array}$ & $\begin{array}{c}0.0120 \\
(0.0075)\end{array}$ \\
\hline Size $_{i, t-1}$ & $\begin{array}{c}0.0002 \\
(0.0004)\end{array}$ & $\begin{array}{c}0.0002 \\
(0.0004)\end{array}$ & $\begin{array}{c}0.0002 \\
(0.0004)\end{array}$ & $\begin{array}{c}0.0002 \\
(0.0004)\end{array}$ \\
\hline Observations & 18,800 & 18,800 & 18,800 & 18,800 \\
\hline R-squared & 0.327 & 0.327 & 0.327 & 0.328 \\
\hline Adjusted R-squared & 0.324 & 0.324 & 0.325 & 0.325 \\
\hline
\end{tabular}

This table reports OLS coefficient estimates of different specifications of the model $l l p_{i, t}=\Lambda \cdot X_{i, t}+\gamma_{1} \times \% \Delta$ PerCapitaGDP $P_{c, t}+\gamma_{2} \times$ Deficit $_{c, t}+\gamma_{3} \times I_{i, t-1}^{\text {Over }}+\gamma_{4} \times I_{i, t-1}^{\text {Over }} \times$ $\% \Delta$ PerCapitaGDP $P_{c, t}+\gamma_{5} \times I_{i, t-1}^{\text {Over }} \times$ Deficit $_{c, t}+\epsilon_{i, t}$ for the whole sample of banks from 47 countries. Regressions include year, country, and bank-type fixed effects. Country level clustered standard errors are reported in parentheses. ${ }^{* * *}, * *$, and $*$ indicate statistical significance levels of $p<0.01, p<0.5$, and $p<0.1$, respectively. Variables are described in Appendix A 


\subsubsection{Fiscal Policy Interaction with Debt-to-GDP}

While the results of Tables 1.5 and 1.6 provide empirical evidence consistent with the argument that a country's finances represent an aggregate variable that is at least as important as the business cycle, in terms of their effects on banks' provisioning choices (Hypothesis 1), the direct channel linking Deficit $c_{c, t}$ and $l l p_{i, t}$ is still challenging given the extensive set of omitted variables that can jointly affect a country's fiscal policy and banks' financial reporting and the fact that the intervening constructs of government guarantees (direct channel only) and managers' assessment of credit risk (both direct and indirect channel) are not directly measurable.

A possible way to partially address endogeneity concerns and shed more light on the fiscal policy mechanism is to exploit the interaction between my proxy for fiscal policy (Deficit $c_{c, t}$ ) and any other variable whose joint effect with the country's finances is economically meaningful. To empirically test the hypothesis that the association between the flow variables Deficit $c_{c, t}$ and $l l p_{i, t}$ is moderated by the stock variable of the country's debt-to-GDP ratio (Hypothesis 2), I augment the model estimated in the previous subsection to account for the effects of the degree of indebtedness of the country's government (represented by the country's Debt-to-GDP ratio, DebttoGDP $P_{c, t}$, also obtained from the World Bank). To do so, I include the linear term of DebttoGDP $P_{c, t}$ and its interac-

tions with both business cycle $\left(\right.$ DebttoGDP $P_{c, t} \times$ PerCapitaGDP $\left.P_{c, t}\right)$ and fiscal policy $\left(\right.$ DebttoGDP $_{c, t} \times$ Deficit $\left._{c, t}\right)$. I also include in the final specification the interaction terms $\triangle N P L_{i, t+1} \times \% \triangle P$ erCapitaGDP $P_{c, t}$ and $\triangle N P L_{i, t+1} \times$ Deficit $_{c, t}$ leading to the following model (1.5). 


$$
\begin{aligned}
\text { llp }_{i, t}= & \alpha+\gamma_{1} \times \% \Delta \text { PerCapitaGDP } \\
& +\gamma_{c, t} \times \gamma_{2} \times \text { DebttoGicit }_{c, t}+\gamma_{3} \times \text { DebttoGDP }_{c, t}+ \\
& +\gamma_{6} \times \Delta N P L_{i, t+1} \times \% \Delta \text { PerCapitaGDP } \\
& +\gamma_{5, t} \times \text { DebttoGDP }_{c, t} \times \text { Deficit }_{c, t} \\
& +\lambda_{1} \times \text { Ebllp }_{i, j}+\lambda_{2} \times \Delta N P L_{i, t+1}+\lambda_{3} \times \Delta N P L_{i, t}+\lambda_{4} \times \Delta N P L_{i, t-1}+ \\
& +\lambda_{5} \times \Delta N P L_{i, t-2}+\lambda_{6} \times C A P_{i, t-1}+\lambda_{7} \times S i z e_{i, t-1}+\epsilon_{i, t}
\end{aligned}
$$

Results are presented in Table 1.8. Regarding the estimates of Deficit c,t $_{\text {, }}$ DebttoGDP $_{c, t}$ and the interaction term DebttoGDP $P_{c, t} \times D e$ ficit $_{c, t}$, statistically and economically significant (positive) estimates of the coefficients of both Deficit ${ }_{c, t}$ and DebttoGDP $P_{c, t}$ in speficiations that do not include the interaction term (specifications (1-2)) are obtained regardless of the inclusion of the interaction term with the business cycle DebttoGDP $P_{c, t} \times \operatorname{PerCapitaGDP_{c,t}.}$ The positive association between the linear term of DebttoGDP $P_{c, t}$ and $l l p_{i, t}$ is economically consistent with the hypothesis that the economic deterioration of a country's fiscal condition is associated with greater values of loan loss provisions. ${ }^{18}$ However, the same estimates of the isolated effects of De ficit ${ }_{c, t}$ and DebttoGDP $P_{c, t}$ become insignificant when DebttoGDP $P_{c, t} \times$ Deficit $_{c, t}$ is introduced as a covariate (specifications (3$5)$ ), whose coefficient estimates $\left(\gamma_{5}\right)$ are all positive and statistically significant (p-values of $7.2 \%, 3.0 \%$, and $4.5 \%$ ). These results suggest that the relationship between Deficit $t_{c, t}$ and $l l p_{i, t}$ is, indeed, considerably moderated by DebttoGDP $P_{c, t}$.

Regarding the effect of the country's business cycle, surprisingly the introduction of the linear term DebttoGDP $P_{c, t}$ and its interactions considerably reduces the statistical significance of the business cycle "channel" on banks' loan loss

\footnotetext{
${ }^{18}$ Deficit $_{c, t}$ and DebttoGDP $P_{c, t}$ represent different dimensions of a country's fiscal conditions, as the current level of DebttoGDP $P_{c, t}$, among other variables, reflects past fiscal policy decisions.
} 
provisions. Coefficient estimates of $\% \Delta$ PerCapitaGDP $P_{c, t}$ fail to provide evidence that business cycles affect banks' financial reporting in two out of five speci-

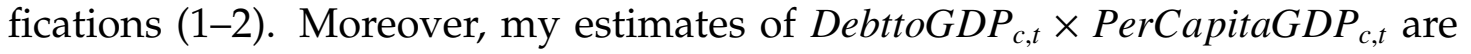
insignificant in all the empirical specifications.

Simply put, based on the results shown in Table 1.8, the positive association between fiscal deficits and loan loss provision is statistically robust and amplified by the country's indebtedness. On the other hand, not only is the econometric evidence of the negative association between business cycles and loan loss provision weaker, but also the country's indebtedness attenuates this effect (if any). The amplification effect reflected by DebttoGDP $P_{c, t} \times$ Deficit $t_{c, t}$ and the insignificant results of DebttoGDP $P_{c, t} \times$ PerCapitaGDP $P_{c, t}$ are consistent with an effect originated from the fiscal condition of a country's government, rather than the country's deficit merely representing another (better) measure of business cycles. ${ }^{19}$

\footnotetext{
${ }^{19}$ I conduct a battery of additional analyses and robustness checks to provide further evidence that governments' deficits proxy for an important macroeconomic state variable which affects bank managers' assessments of credit risk. My baseline results are robust to the inclusion of different econometric controls, including lagged variables for business cycles and fiscal policy to account for the serial relationship between the two variables, originated either by construction or endogenous response, as well as additional macro and geopolitical factors to mitigate concerns of contemporaneous omitted variables that might independently affect banks' provisioning decisions. See Appendix B
} 
Table 1.8: Fiscal Policy and Business Cycles — Results Interacting with Debt-to-GDP

\begin{tabular}{|c|c|c|c|c|c|}
\hline & \multicolumn{5}{|c|}{ Dep. variable $=l l p_{i, t}$} \\
\hline & (1) & (2) & (3) & $(4)$ & (5) \\
\hline$\% \Delta$ PerCapitaGDP $P_{c, t}$ & $\begin{array}{c}-0.0054 \\
(0.0045)\end{array}$ & $\begin{array}{c}-0.0064 \\
(0.0073)\end{array}$ & $\begin{array}{c}-0.0075 * \\
(0.0044)\end{array}$ & $\begin{array}{c}-0.0116 * \\
(0.0068)\end{array}$ & $\begin{array}{c}-0.0120 * \\
(0.0060)\end{array}$ \\
\hline Deficit $_{c, t}$ & $\begin{array}{l}0.0429 * * \\
(0.0208)\end{array}$ & $\begin{array}{l}0.0429 * * \\
(0.0210)\end{array}$ & $\begin{array}{c}-0.0022 \\
(0.0228)\end{array}$ & $\begin{array}{r}-0.0080 \\
(0.0202)\end{array}$ & $\begin{array}{c}0.0059 \\
(0.0232)\end{array}$ \\
\hline DebttoGDP $P_{c, t}$ & $\begin{array}{l}0.0001 * * * \\
(0.0000)\end{array}$ & $\begin{array}{l}0.0001 * * * \\
(0.0000)\end{array}$ & $\begin{array}{c}0.0000 \\
(0.0001)\end{array}$ & $\begin{array}{c}0.0000 \\
(0.0001)\end{array}$ & $\begin{array}{c}0.0000 \\
(0.0001)\end{array}$ \\
\hline DebttoGDP $_{c, t} \times$ PerCapitaGDP $P_{c, t}$ & & $\begin{array}{c}0.0000 \\
(0.0001)\end{array}$ & & $\begin{array}{c}0.0001 \\
(0.0001)\end{array}$ & $\begin{array}{c}0.0001 \\
(0.0001)\end{array}$ \\
\hline DebttoGDP $_{c, t} \times$ Deficit $_{c, t}$ & & & $\begin{array}{c}0.0010 * \\
(0.0005)\end{array}$ & $\begin{array}{l}0.0011 * * \\
(0.0005)\end{array}$ & $\begin{array}{l}0.0010 * * \\
(0.0004)\end{array}$ \\
\hline$\Delta N P L_{i, t+1} \times \% \Delta$ PerCapitaGDP $P_{c, t}$ & & & & & $\begin{array}{r}-0.1271 \\
(0.1503)\end{array}$ \\
\hline$\Delta N P L_{i, t+1} \times$ Deficit $_{c, t}$ & & & & & $\begin{array}{c}-0.8852 * \\
(0.5101)\end{array}$ \\
\hline Ebllp $_{i, t}$ & $\begin{array}{l}0.0873 * * * \\
(0.0172)\end{array}$ & $\begin{array}{l}0.0872 * * * \\
(0.0174)\end{array}$ & $\begin{array}{l}0.0869 * * * \\
(0.0171)\end{array}$ & $\begin{array}{l}0.0865 * * * \\
(0.0174)\end{array}$ & $\begin{array}{l}0.0869 \text { *** } \\
(0.0178)\end{array}$ \\
\hline$\triangle N P L_{i, t+1}$ & $\begin{array}{c}-0.0073 \\
(0.0219)\end{array}$ & $\begin{array}{c}-0.0073 \\
(0.0220)\end{array}$ & $\begin{array}{c}-0.0093 \\
(0.0217)\end{array}$ & $\begin{array}{c}-0.0096 \\
(0.0215)\end{array}$ & $\begin{array}{c}0.0121 \\
(0.0185)\end{array}$ \\
\hline$\triangle N P L_{i, t}$ & $\begin{array}{l}0.2892 * * * \\
(0.0184)\end{array}$ & $\begin{array}{l}0.2903 * * * \\
(0.0188)\end{array}$ & $\begin{array}{l}0.2893 * * * \\
(0.0188)\end{array}$ & $\begin{array}{l}0.2914 * * * \\
(0.0191)\end{array}$ & $\begin{array}{l}0.2925 * * * \\
(0.0201)\end{array}$ \\
\hline$\triangle N P L_{i, t-1}$ & $\begin{array}{c}0.0023 \\
(0.0020)\end{array}$ & $\begin{array}{c}0.0024 \\
(0.0021)\end{array}$ & $\begin{array}{c}0.0022 \\
(0.0020)\end{array}$ & $\begin{array}{c}0.0022 \\
(0.0020)\end{array}$ & $\begin{array}{c}0.0012 \\
(0.0024)\end{array}$ \\
\hline$\triangle N P L_{i, t-2}$ & $\begin{array}{c}-0.0001 * * * \\
(0.0000)\end{array}$ & $\begin{array}{c}-0.0001 * * * \\
(0.0000)\end{array}$ & $\begin{array}{c}-0.0001 * * * \\
(0.0000)\end{array}$ & $\begin{array}{c}-0.0001 * * * \\
(0.0000)\end{array}$ & $\begin{array}{c}-0.0001 * * * \\
(0.0000)\end{array}$ \\
\hline$C A P_{i, t-1}$ & $\begin{array}{c}0.0124 * \\
(0.0064)\end{array}$ & $\begin{array}{c}0.0124 * \\
(0.0063)\end{array}$ & $\begin{array}{c}0.0126 * \\
(0.0064)\end{array}$ & $\begin{array}{c}0.0127 * \\
(0.0063)\end{array}$ & $\begin{array}{c}0.0125 * \\
(0.0064)\end{array}$ \\
\hline$S_{i z e_{i, t-1}}$ & $\begin{array}{c}0.0004 \\
(0.0004)\end{array}$ & $\begin{array}{c}0.0004 \\
(0.0004)\end{array}$ & $\begin{array}{c}0.0004 \\
(0.0004)\end{array}$ & $\begin{array}{c}0.0004 \\
(0.0004)\end{array}$ & $\begin{array}{c}0.0004 \\
(0.0004)\end{array}$ \\
\hline Observations & 13,867 & 13,867 & 13,867 & 13,867 & 13,867 \\
\hline R-squared & 0.319 & 0.319 & 0.321 & 0.321 & 0.323 \\
\hline Adjusted R-squared & 0.315 & 0.315 & 0.317 & 0.317 & 0.320 \\
\hline
\end{tabular}

This table reports OLS coefficient estimates of different specifications of the model $l l p_{i, t}=\Lambda \cdot X_{i, t}+\gamma_{1} \times$ $\% \Delta$ PerCapitaGDP $P_{c, t}+\gamma_{2} \times$ Deficit $_{c, t}+\gamma_{3} \times$ DebttoGDP $_{c, t}+\gamma_{4} \times$ DebttoGDP $_{c, t} \times \% \Delta$ PerCapitaGDP $P_{c, t}+\gamma_{5} \times$ DebttoGDP $_{c, t} \times$ Deficit $_{c, t}+\gamma_{6} \times \Delta N P L_{i, t+1} \times \% \Delta$ PerCapitaGDP $P_{c, t}+\gamma_{7} \times \Delta N P L_{i, t+1} \times$ Deficit $_{c, t}+\epsilon_{i, t}$ for the whole sample of banks from 47 countries. Regressions include year, country, and bank-type fixed effects. Country level clustered standard errors are reported in parentheses. ${ }^{* * *}$, **, and * indicate statistical significance levels of $p<0.01, p<0.5$, and $p<0.1$, respectively. Variables are described in Appendix A 


\subsection{Instrumental Variables Estimation: Levels and Innovations of Defense Expenditures}

\subsubsection{Identifying Fiscal Shocks}

Although my empirical results so far are robust to different samples and the inclusion of different sets of covariate controls, the jointly endogenous nature of business cycles (\% $\triangle$ PerCapitaGDP $\left.P_{c, t}\right)$ and the government's fiscal policy (Deficit $t_{c, t}$ ) still imposes a burden on the actual identification of the hypothesized effects originated from fiscal policy decisions. The ideal setting for enhancing the internal validity of this direct effect on banks' loan loss provisions would be to identify sources of variation in Deficit $t_{c, t}$ which are exogenous to business cy-

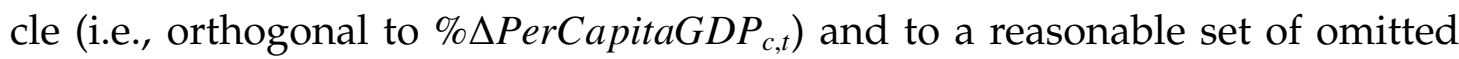
variables that could also affect banks' reporting decisions.

Ramey (2011) advocates the use of defense spending data to identify fiscal shocks, given that fluctuations in defense spending account for almost all innovations in total government spending. The economic argument for the exogenous nature of defense spending is twofold. Non-defense government spending (e.g., entitlement programs, social security, etc.) do have a strong persistency component in the time series given that the economic conditions leading to such spending decisions (unemployment conditions, aging population, etc.) are persistent. Moreover, these economic variables are strongly related to the business cycle. Defense spending decisions, however, are normally made based on geopolitical factors less related to short-term economic output.

The literature emphasizes two main empirical approaches to identify and 
estimate the effects of unanticipated government spending: the vector autoregressive (VAR) approach and the Ramey and Shapiro (1998) Narrative Approach. A vast literature relies on VAR techniques to study the effect of government spending shocks (Rotemberg and Woodford, 1997; Blanchard and Perotti, 2002; Fatás and Mihov, 2001, 2003; Galí, López-Salido, and Vallés, 2007). More recently, Berndt, Lustig, and Yeltekin (2012) built upon the approach of Ramey (2011) to identify fiscal shocks based on defense spending, showing that most unanticipated government spending is financed through a subsequent increase in fiscal surplus.

Ramey and Shapiro (1998) isolate the political events leading to large military buildups using a narrative approach based on historical accounts and Business Week discussions. They show that a simple dummy variable taking nonzero values in three periods identified by their narrative approach significantly increases the explanatory power of their econometric estimates for a variety of macroeconomic variables. ${ }^{20}$

I exploit a comprehensive dataset of military expenditures for different countries compiled by the Stockholm International Peace Research Institute $(\mathrm{SIPRI})^{21}$. For each of the 47 countries comprising my sample I compute $D e f_{c, t}$ as the ratio between the government's defense and military expenditures and the country's GDP. Under the assumption that defense expenditures are government decisions made based on factors unrelated to the business cycle, this variable is my first candidate to instrument the endogenous variable Deficit $t_{c, t}$.

\footnotetext{
${ }^{20}$ In their original work, Ramey and Shapiro (1998) identify three periods of military buildup: the Korean War, the Vietnam War, and the later Carter-Reagan buildup. Ramey (2011) later augments this sample to four periods, including the 9/11 Terrorist Attacks to further compare the VAR and the Narrative Approach.

${ }^{21}$ The data is available at http://www.sipri.org/databases/milex and is also used by prior academic research (see Chen et al. 2016)
} 
Even assuming $D e f_{c, t}$ is primarily driven by geopolitical factors, levels of defense spending are certainly less exogenous than innovations to defense spending, which should reflect temporal variation in foreign (and domestic) policy.

To further identify innovations to $D e f_{c, t}$ I perform the following VAR estimation. For a given country $c$, I estimate the model described by equation (1.6), where $Y_{c, t}$ is a three-dimensional vector including the country's military expenditures by GDP $\left(D e f_{c, t}\right)$, the country's percent variation in GDP per capita $\left(\% \triangle\right.$ PerCapitaGDP $\left.P_{c, t}\right)$, and the log of the aggregate military expenditures for all countries with available data in the sample from 1985 to 2015 (named $\left.\log M i l_{t}\right)$, and where $A(L)$ is a lag-operator matrix applied on vector $Y_{c, t}$. I include $\% \triangle P e r C a p i t a G D P_{c, t}$ in my VAR estimate to account for the serial autocorrelation between business cycles and government spending on military. The third component is considered because the World's aggregate spending on military is a proxy for global instability - which may lead individual countries to spend more/less on their own military.

$$
\begin{array}{r}
Y_{c, t}=A(L) Y_{c, t-L}+U_{c, t}, \quad \forall c \\
Y_{c, t} \equiv\left(\operatorname{Def}_{c, t} \% \Delta \text { PerCapitaGDP } P_{c, t} \log \operatorname{Mil}_{t}\right)
\end{array}
$$

I consider the estimation of the VAR model described by equation (1.6) with one, two, and three lags of $Y_{c, t}$. The time-series evolution of the first component of each estimated $\widehat{U}_{c, t}$ is used to construct an empirical proxy for innovations to military expenditures - henceforth referred to as $\operatorname{ResAR}(1)_{c, t}, \operatorname{Res} A R(2)_{c, t}$ and $\operatorname{ResAR}(3)_{c, t}$, respectively, for VAR estimates with $L=1,2,3$. These innovations correspond to my additional candidates to instrument De ficit $c_{c, t}$.

Figures 1.4 to 1.7 depict the time-series evolution of military expenditures (upper plots) and innovations to these spendings (lower plots) for four coun- 
tries (United States, France, India and Singapore). Anecdotal facts drawn from geopolitical events can be made to support the hypothesis of the innovation series capturing unanticipated events that led to sudden variations in military expenditures which, ultimately, affected the countries' fiscal conditions. For example, negative innovations for the United States (Figure 1.4) in 1991 coincide with the dissolution of the Soviet Union and end of the Cold War, whereas positive innovations in 2002 correspond to the military buildup that arose after the 9/11 Terrorist Attacks. France (Figure 1.5), as a NATO Member, also experienced similar positive innovations to $D e f_{c, t}$ contemporaneously to these attacks and the subsequent War on Terror. More remarkably, a spike in France's military spending in 2009 relates to President Nicolas Sarkozy's decision to give up France's special role in NATO, rejoining NATO's integrated military command and overturning Charles de Gaulle's belief that "full membership undermines France's sovereignty" (Erlanger, 2009; Simons, 2009; Pesme, 2010). Positive innovations in India (Figure 1.6) around 1999 and 2004, respectively, coincided with unanticipated nuclear tests conducted by Pakistan (1998) and the Kargil War (1999) between the two nations and following the completion of the Line of Control fencing (2004). The positive shock observed in India's defense spending in 2009 corresponds to the military buildup which followed the 11/26/2008 Mumbai attacks (Majumdar, 2009). Last, strong oscillations in innovations in Singapore reflect the country's specific defense needs given its geographic location and geopolitical importance (see Figure 1.7).22

\footnotetext{
${ }^{22}$ For instance, the unexpected soar in defense spending of Singapore in 1998 corresponds to sharpening tensions with Malaysia.
} 
Levels of Defense Spending (United States)

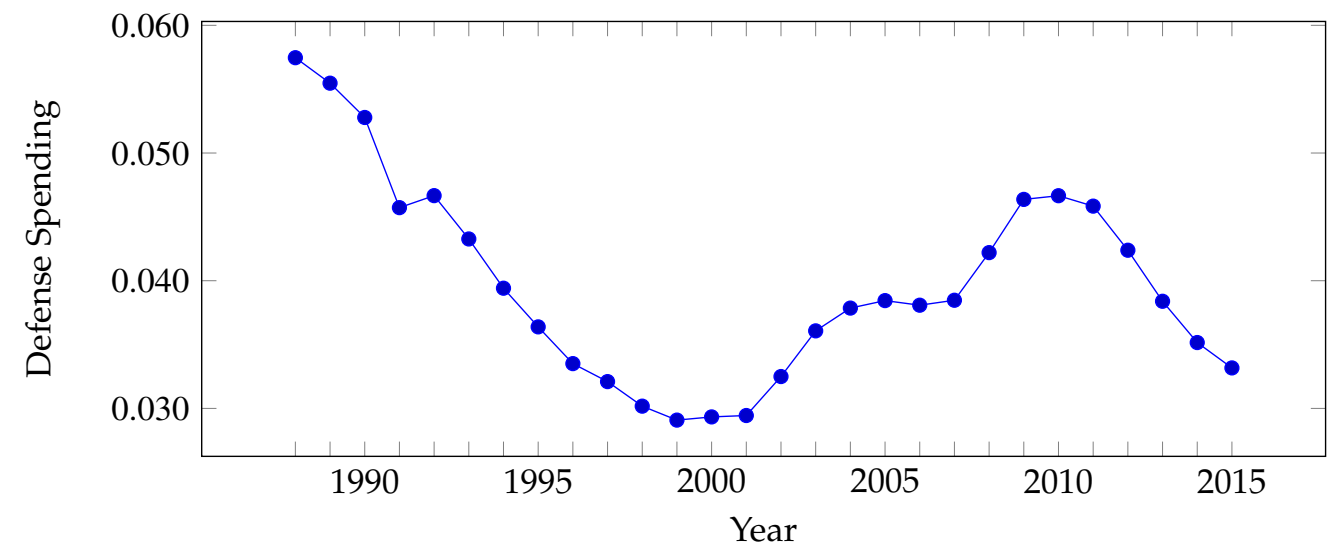

Innovations of Defense Spending (United States)

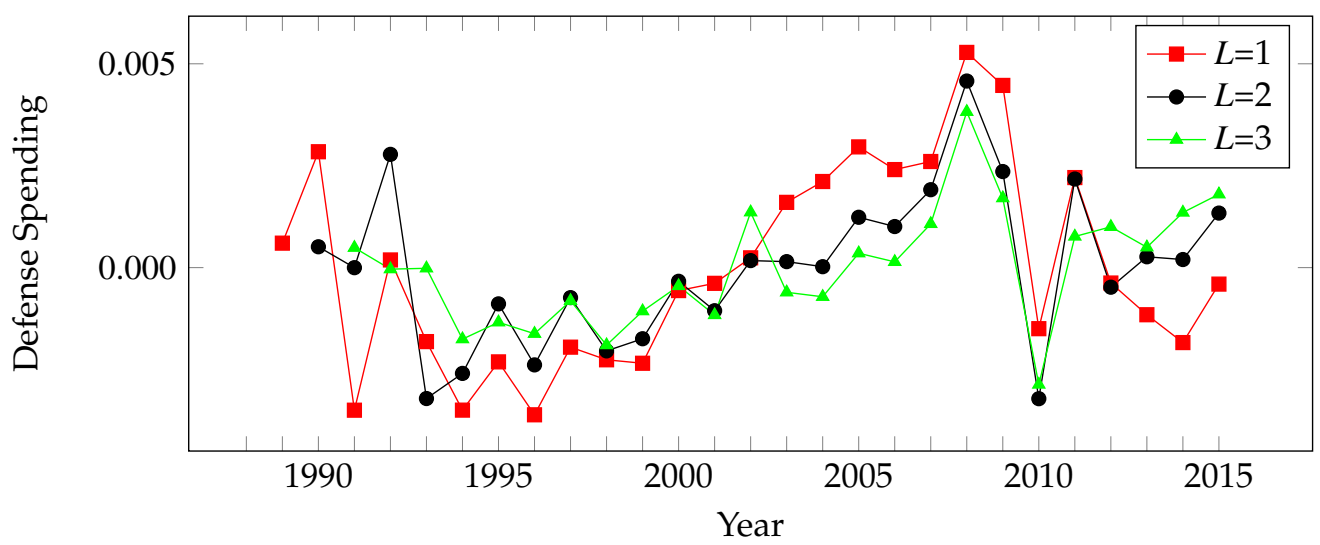

Figure 1.4: Defense Spending Levels and Innovations — United States 
Levels of Defense Spending (France)

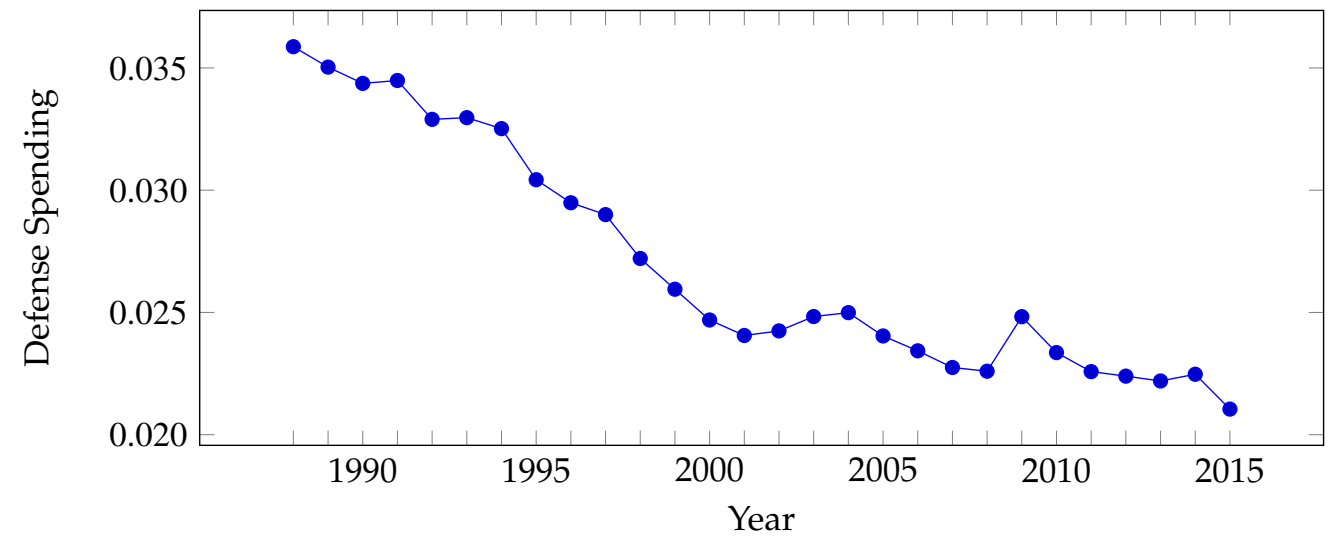

Innovations of Defense Spending (France)

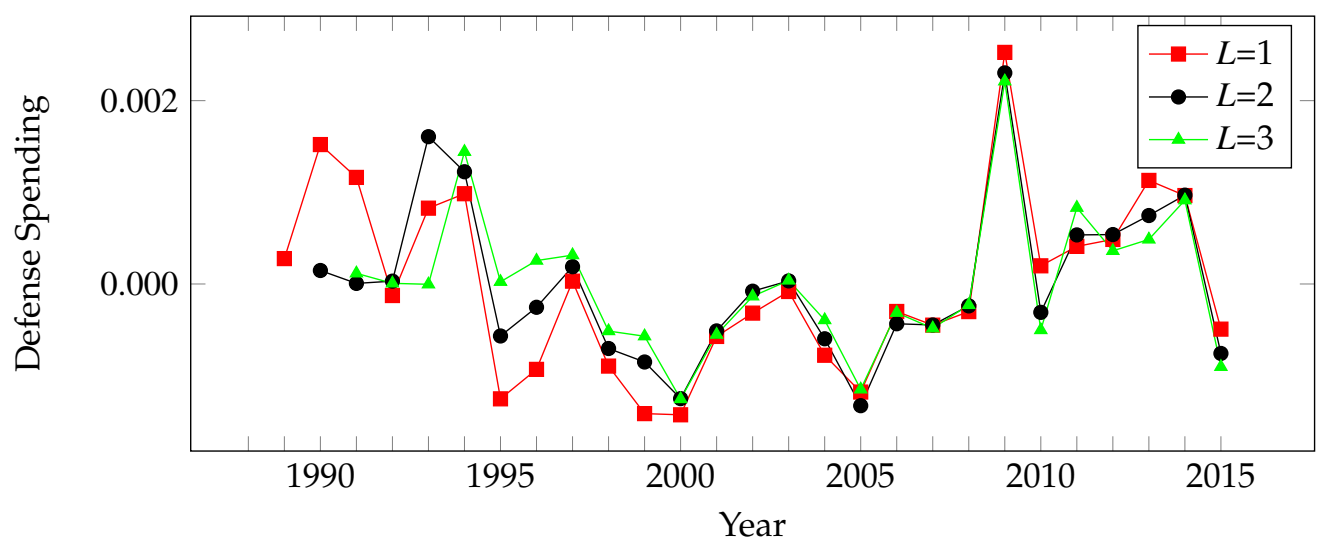

Figure 1.5: Defense Spending Levels and Innovations — France 
Levels of Defense Spending (India)

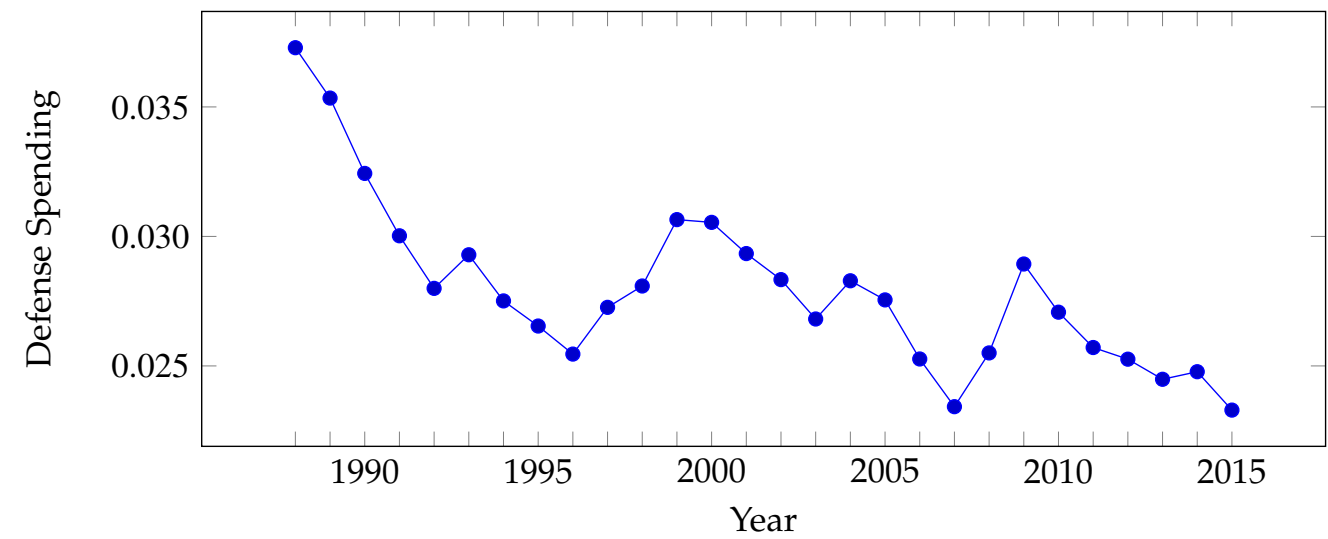

Innovations of Defense Spending (India)

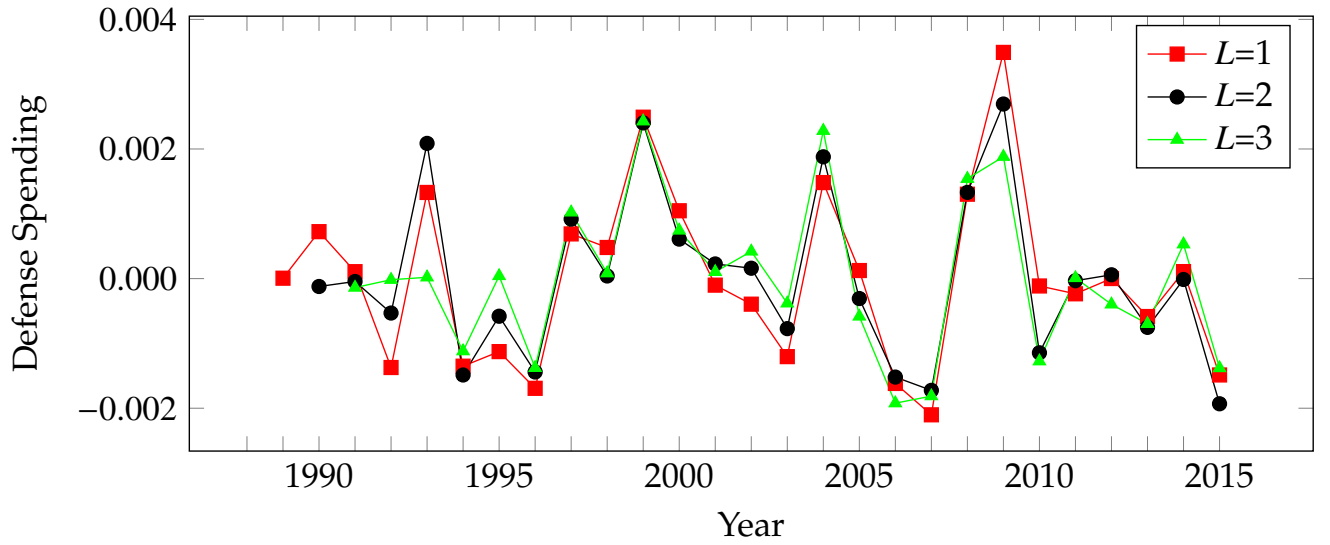

Figure 1.6: Defense Spending Levels and Innovations — India 
Levels of Defense Spending (Singapore)

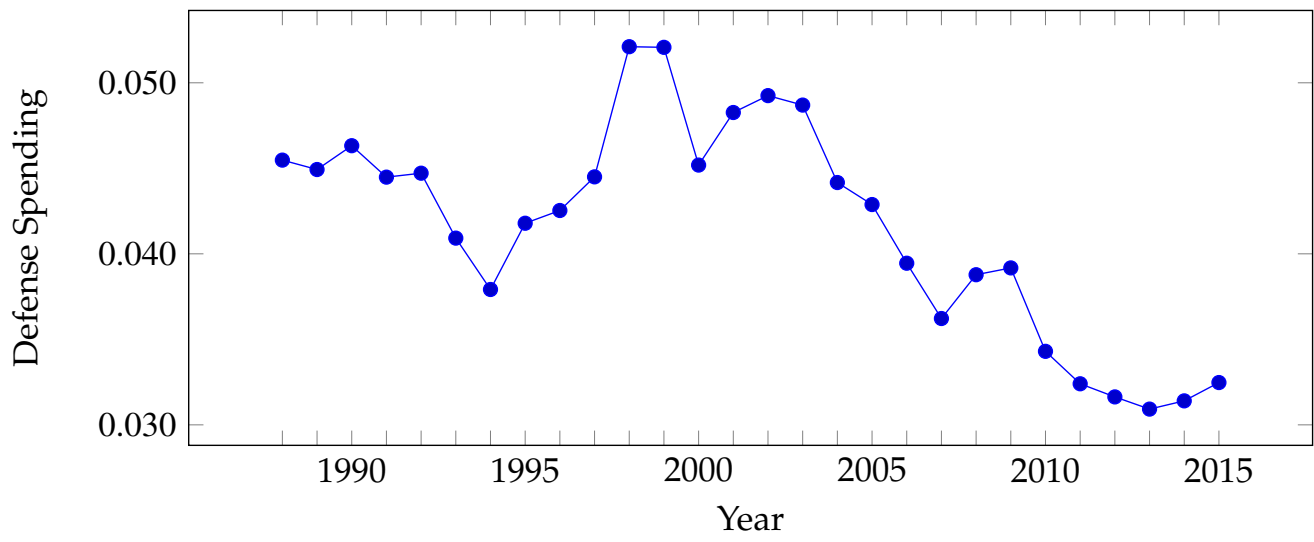

Innovations of Defense Spending (Singapore)

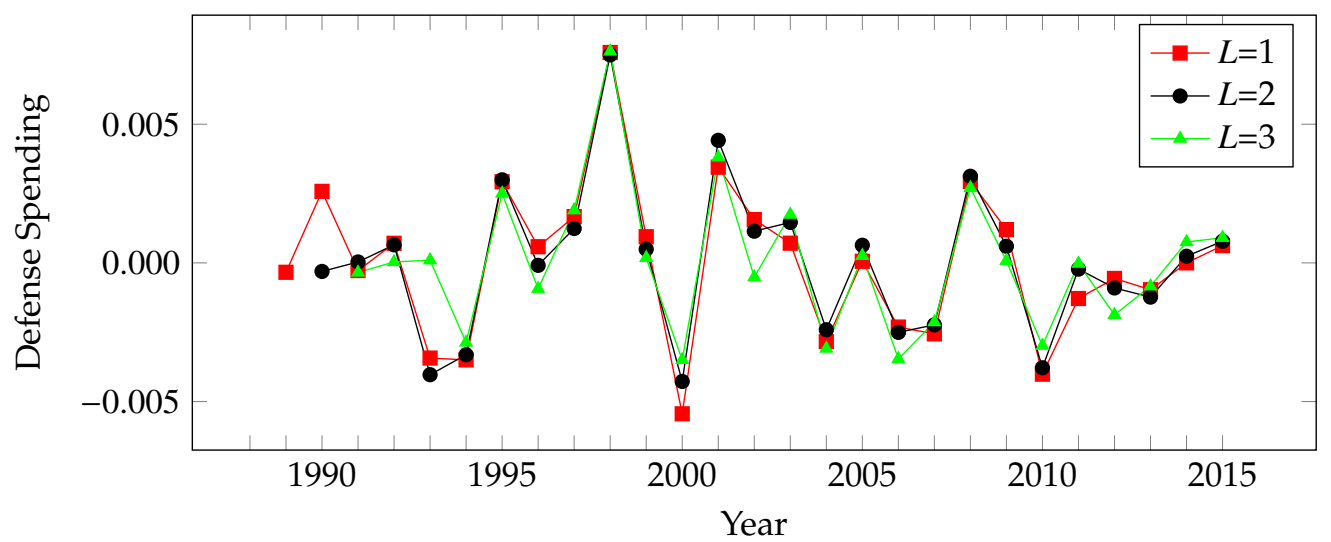

Figure 1.7: Defense Spending Levels and Innovations — Singapore

\subsubsection{Deficits and Loan Loss Provisions: IV Estimation}

To estimate the effect of military expenditures (and their innovations) on governments' fiscal policy and, finally, on banks' provisioning, I estimate the following instrumental variables specification whose first and second stages are described by equations (1.7) and (1.8) by using a two-stage least-squares (2SLS) 
approach.

$$
\begin{gathered}
\text { Deficit }_{c, t}=\rho+\beta_{1} \times \% \Delta \text { PerCapitaGDP } \\
c, t+\beta_{2} \times \text { Instrument }_{c, t}+\Sigma \cdot X_{i, t}+\psi_{i, t} \\
\operatorname{ll}_{i, t}=\alpha+\gamma_{1} \times \% \Delta \text { PerCapitaGDP } P_{c, t}+\gamma_{2} \times \widehat{\text { Deficit }_{c, t}}+\Lambda \cdot X_{i, t}+\epsilon_{i, t}
\end{gathered}
$$

Table 1.9 reports the coefficient estimates for the first-stage regression model (1.7). Columns $(1-4)$ show statistically significant coefficients ( $p$-values $<0.01$ ) for the four choices of Instrument $c_{c, t} \equiv\left\{\operatorname{Def} f_{c, t}, \operatorname{ResAR}(1)_{c, t}, \operatorname{ResAR}(2)_{c, t}, \operatorname{ResAR}(3)_{c, t}\right\}$, all of which are positive since unexpected shocks to government expenditures are, by construction, positively related to the government's deficit Deficit $t_{c, t}$. Statistically insignificant coefficient estimates on $\% \triangle P \operatorname{PerCapitaGDP_{c,t}}$ support the argument that the association between defense expenditures (Instrument $t_{c, t}$ ) and countries' deficits is not affected by the contemporaneous effects of business cycles.

Table 1.10 reports the 2SLS coefficient estimates for the second-stage reduced-form expression (1.8). Coefficient estimates of $\gamma_{2}$ when instrumented by each of the choices of Instrument $t_{c, t}$ are all positive and economically more significant than the coefficient estimate of the business cycle effect. ${ }^{23}$ Regarding their statistical significance, the fiscal policy coefficient estimates are significant at the $1 \%$ level when instrumented by $\operatorname{De} f_{c, t}$, at the $5 \%$ level when $\operatorname{Res} A R(1)_{c, t}$

\footnotetext{
${ }^{23}$ It is important to note that the economic magnitude of the 2SLS coefficient estimates of $\widehat{\text { Deficit }}_{c, t}^{\text {Def }}, \widehat{\text { Deficit }}_{c, t}^{\text {ResAR(1) }}, \widehat{\operatorname{Deficit}}_{c, t}^{\text {ResAR(2) }}$, and $\widehat{\operatorname{Deficit}}_{c, t}^{\operatorname{ResAR}(3)}$ are all greater than the OLS coefficient estimates of Deficit $t_{c, t}$ of the main OLS result (Table 1.5). A possible economic explanation is that variations in Deficit $c_{c, t}$ arising from a wide range of fiscal policy choices may have two competing effects. On the one hand, a more aggresive fiscal policy (i.e., positive variations in De $_{\text {icit }} t_{c, t}$ ) may compromise the government's ability to bail out banks or credibility to stimulate the economy in the future, thereby forcing banks to increase their loan loss provisions. On the other hand, such policies, if well implemented, may have positive contemporaneous effects on the business cycle, causing banks to decrease their provisions. Variations in Deficit $t_{c, t}$ originated purely from military spending may nevertheless have a weaker effect of contemporaneous stimuli, hence presenting a cleaner setting to test the mechanism hypothesized in Subsection 1.2.4.
} 
and $\operatorname{Res} A R(3)_{c, t}$ are considered, and at the $10 \%$ level when the VAR(2) model is fitted.

The advantage of exploiting fiscal shocks in an instrumental variables specification is that it supports the argument that the statistical association between governments' finances and banks' provisioning choices is determined by fiscal policy choices. Differently put, while OLS estimations including lagged terms and additional proxies respectively address concerns of serial correlation and omitted variables, they do not identify the exact sources of variation in Deficit $_{c, t}$. Fiscal shocks arising from innovations to defense expenditures provide a cleaner test of my hypothesis given that the primary sources leading to these budgetary decisions are strategic or geopolitical, therefore unlikely to be decisions whose objectives (cause) are related to business cycles.

These results should be interpreted with caution. While being empirically consistent with the direct channel of fiscal policy, they do not rule out potential effects from the indirect channel. For example, in countries where defense spending comprises a significant fraction of the government's budget (e.g., the United States), even unanticipated changes in such expenditures may represent additional (unintended) effects to the real economy - either a contemporaneous stimulus or a fiscal crisis that alters consumer sentiment and expectations of the private sector.

Moreover, the use of military spending data to identify fiscal shocks comes with two caveats to support the exclusion restriction of the instrument. First, levels and innovations to defense expenditures, when considerably large, may not only affect the government's deficit but also be associated with major military conflicts which also affect banks' provisioning through their effects on the 
Table 1.9: Instrumental Variables Estimation — First-stage Coefficient Estimates

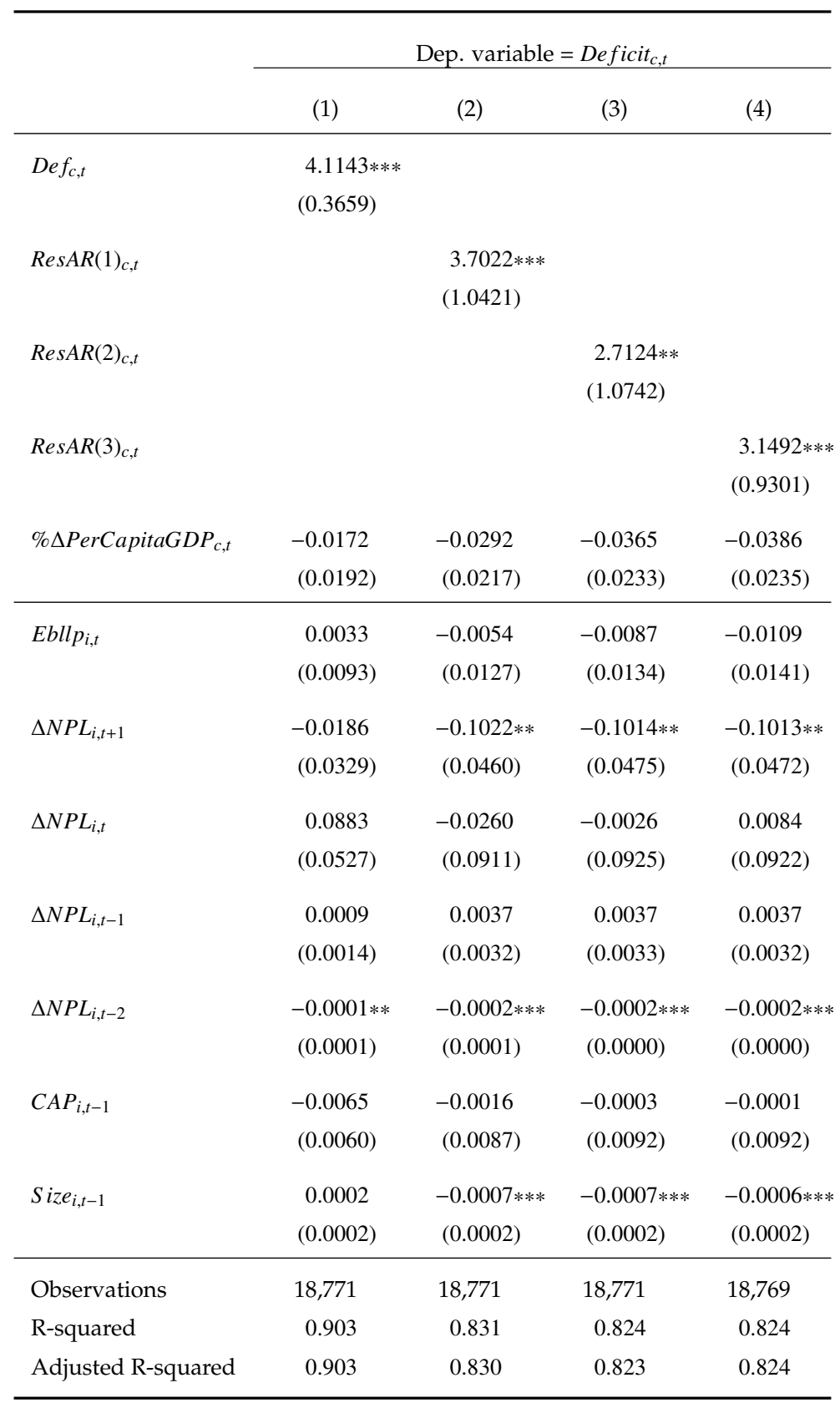

This table reports coefficient estimates of the first-stage model Deficit $c_{c, t}=$ $\rho+\beta_{1} \times \% \Delta$ PerCapitaGDP $P_{c, t}+\beta_{2} \times$ Instrument $_{c, t}+\Sigma \cdot X_{i, t}+\psi_{i, t}$, where the four choices of Instrument $t_{c, t}$ are (i) levels of defense spending by GDP $\left(\right.$ Def $\left._{c, t}\right)$ and (ii) innovations of defense spending estimated with VAR models with one, two, and three lagged terms. Regressions include year, country, and banktype fixed effects. Country level clustered standard errors are reported in parentheses. ${ }^{* * *},{ }^{* *}$, and ${ }^{*}$ indicate statistical significance levels of $p<0.01$, $p<0.5$, and $p<0.1$, respectively. Variables are described in Appendix A 
Table 1.10: Instrumental Variables Estimation — Second-stage (2SLS) Estimates

\begin{tabular}{|c|c|c|c|c|}
\hline & \multicolumn{4}{|c|}{ Dep. variable $=l l p_{i, t}$} \\
\hline & (1) & $(2)$ & (3) & (4) \\
\hline$\widehat{\text { Deficit }}_{c, t}{ }^{\text {Def }}$ & $\begin{array}{l}0.1344 * * * \\
(0.0229)\end{array}$ & & & \\
\hline$\widehat{\text { Deficit }}_{c, t} \operatorname{ResAR}(1)$ & & $\begin{array}{l}0.1063 * * \\
(0.0464)\end{array}$ & & \\
\hline$\widehat{\text { Deficit }}_{c, t} \operatorname{ResAR}(2)$ & & & $\begin{array}{c}0.1265 * \\
(0.0647)\end{array}$ & \\
\hline$\widehat{\text { Deficit }}_{c, t} \operatorname{ResAR}(3)$ & & & & $\begin{array}{l}0.1434 * * \\
(0.0590)\end{array}$ \\
\hline$\% \Delta$ PerCapitaGDP $P_{c, t}$ & $\begin{array}{c}-0.0098 * \\
(0.0054)\end{array}$ & $\begin{array}{r}-0.0113 \\
(0.0072)\end{array}$ & $\begin{array}{r}-0.0102 \\
(0.0079)\end{array}$ & $\begin{array}{r}-0.0094 \\
(0.0071)\end{array}$ \\
\hline Ebllp $_{i, t}$ & $\begin{array}{l}0.0781 * * * \\
(0.0149)\end{array}$ & $\begin{array}{l}0.0777 * * * \\
(0.0147)\end{array}$ & $\begin{array}{l}0.0780 * * * \\
(0.0146)\end{array}$ & $\begin{array}{l}0.0782 \text { *** } \\
(0.0147)\end{array}$ \\
\hline$\triangle N P L_{i, t+1}$ & $\begin{array}{c}0.0001 \\
(0.0240)\end{array}$ & $\begin{array}{r}-0.0025 \\
(0.0264)\end{array}$ & $\begin{array}{r}-0.0006 \\
(0.0283)\end{array}$ & $\begin{array}{c}0.0010 \\
(0.0279)\end{array}$ \\
\hline$\triangle N P L_{i, t}$ & $\begin{array}{l}0.2863 * * * \\
(0.0241)\end{array}$ & $\begin{array}{l}0.2862 * * * \\
(0.0232)\end{array}$ & $\begin{array}{l}0.2862 * * * \\
(0.0238)\end{array}$ & $\begin{array}{l}0.2854 * * * \\
(0.0245)\end{array}$ \\
\hline$\triangle N P L_{i, t-1}$ & $\begin{array}{c}0.0034 \\
(0.0030)\end{array}$ & $\begin{array}{c}0.0035 \\
(0.0030)\end{array}$ & $\begin{array}{c}0.0035 \\
(0.0029)\end{array}$ & $\begin{array}{c}0.0034 \\
(0.0029)\end{array}$ \\
\hline$\triangle N P L_{i, t-2}$ & $\begin{array}{c}-0.0001 \text { *** } \\
(0.0000)\end{array}$ & $\begin{array}{c}-0.0001 * * * \\
(0.0000)\end{array}$ & $\begin{array}{c}-0.0001 * * * \\
(0.0000)\end{array}$ & $\begin{array}{c}-0.0001 * * * \\
(0.0000)\end{array}$ \\
\hline$C A P_{i, t-1}$ & $\begin{array}{c}0.0114 \\
(0.0071)\end{array}$ & $\begin{array}{c}0.0114 \\
(0.0071)\end{array}$ & $\begin{array}{c}0.0114 \\
(0.0071)\end{array}$ & $\begin{array}{c}0.0114 \\
(0.0070)\end{array}$ \\
\hline$S_{i z e_{i, t-1}}$ & $\begin{array}{c}0.0003 \\
(0.0004)\end{array}$ & $\begin{array}{c}0.0003 \\
(0.0004)\end{array}$ & $\begin{array}{c}0.0003 \\
(0.0004)\end{array}$ & $\begin{array}{c}0.0003 \\
(0.0004)\end{array}$ \\
\hline Observations & 18,771 & 18,771 & 18,771 & 18,769 \\
\hline R-squared & 0.316 & 0.321 & 0.318 & 0.314 \\
\hline Adjusted R-squared & 0.314 & 0.318 & 0.315 & 0.312 \\
\hline
\end{tabular}

This table reports 2SLS coefficient estimates of the model $l l p_{i, t}=\alpha+\gamma_{1} \times$ $\% \Delta$ PerCapitaGDP $P_{c, t}+\gamma_{2} \times \widehat{\text { Deficit }}_{c, t}+\Lambda \cdot X_{i, t}+\epsilon_{i, t}$, where the Deficit $c_{c, t}$ is instrumented by the four choices of Instrument $t_{c, t}$. Regressions include year, country, and bank-type fixed effects. Country level clustered standard errors are reported in parentheses. ${ }^{* * *}, * *$, and ${ }^{*}$ indicate statistical significance levels of $p<0.01, p<0.5$, and $p<0.1$, respectively. Variables are described in Appendix $\mathrm{A}$ 
real economy. Second, even if military escalations evolve as diplomatic tensions rather than open conflicts, the simple threat of a war may have a first-order effect on bank managers' expectations of economic activity. To mitigate these concerns, in the following subsection I perform a battery of additional empirical tests to provide supporting evidence of the exclusion restriction of such fiscal shocks.

\subsubsection{Analysis of Exclusion Restriction}

In this subsection I present results from additional empirical tests conducted to bolster my arguments on the exclusion restriction of the instrumental variables setting which exploits military spending data to identify fiscal shocks. Although governments' decisions to invest in national defense are primarily made as a

consequence of strategic reasons, such policies do not preclude the existence of contemporaneous and subsequent effects on the business cycle. Such effects can be broadly classified as follows:

1. Actual business cycle effects (affecting lenders and borrowers) due to actual military conflicts.

2. Actual business cycle effects due to the lenders' and borrowers' subjective expectations of military conflicts.

3. Contemporaneous and long-term effects of military spending on the business cycle (i.e, economic stimuli or deterioration).

I discuss how different tests can address each of the aforementioned concerns. 
Regarding the first concern, one of the advantages of my sample period (1996-2014) is that it comprises escalating tensions between countries (as well as reconciliations), military campaigns (e.g., War on Terror) or even actual confrontations, but not major conflicts such as World War II, the Korean War, and the Vietnam War. To investigate whether levels (and innovations) of military spending are associated with any variation in the actual credit risk of the banks in my sample, I perform an OLS estimate of the following reduced-form specification:

$$
\begin{aligned}
\Delta N P L_{i, t+1}= & \beta_{0}+\beta_{1} \times \text { Instrument }_{c, t}+\beta_{2} \times \Delta N P L_{i, t}+ \\
& +\beta_{3} \times \Delta N P L_{i, t-1}+\beta_{4} \times \Delta N P L_{i, t-2}+\epsilon_{i, t}
\end{aligned}
$$

where Instrument $t_{c, t}$ are the four choices of instrument used in subsection 1.4.2. Coefficient estimates, depicted in Table 1.11, fail to provide evidence that positive variations in defense expenditures are associated with worsened creditworthiness of banks' loan portfolios.

Although the results of Table 1.11 are consistent with the argument that such military buildups are not sufficiently large to lead to contemporaneous real effects reflected in banks' credit losses, they do not rule out that higher levels of loan loss provisions are associated with positive innovations of military spending, not through the effect of such policies on the countries' deficits but because of managers' expectations of potential wars.

To alleviate concerns that this alternative explanation is what is driving my IV results, I augment the baseline model of loan loss provisions to include both Deficit $_{c, t}$ and the defense news terms $\left(\operatorname{ResAR}(1)_{c, t}, \operatorname{Res} A R(2)_{c, t}\right.$, and $\left.\operatorname{Res} A R(3)_{c, t}\right)$ as independent variables. Coefficient estimates are reported in Table 1.12 
The combination of statistically insignificant coefficient estimates of all three proxies of military spending innovations with positive and statistically significant $(\mathrm{p}<1 \%)$ estimates of Deficit $_{c, t}$ in all three specifications provide supporting evidence that managers' expectations of conflicts have no significant impact in their provisioning decisions. Taken together, the results of Tables 1.12 and 1.10 suggest that innovations to defense spending affect banks' loan loss provisions only through their effect on governments' deficits.

Table 1.11: Defense Expenditures and Future Nonperforming Loans

\begin{tabular}{|c|c|c|c|c|}
\hline & \multicolumn{4}{|c|}{ Dep. variable $=\Delta N P L_{i, t}$} \\
\hline & (1) & (2) & (3) & (4) \\
\hline \multirow[t]{2}{*}{$D e f_{c, t}$} & $-0.2482 *$ & & & \\
\hline & $(0.1451)$ & & & \\
\hline \multirow[t]{2}{*}{$\operatorname{ResAR}(1)_{c, t}$} & & 0.5680 & & \\
\hline & & $(0.5130)$ & & \\
\hline \multirow[t]{2}{*}{$\operatorname{ResAR}(2)_{c, t}$} & & & 0.6681 & \\
\hline & & & $(0.5302)$ & \\
\hline \multirow[t]{2}{*}{$\operatorname{ResAR}(3)_{c, t}$} & & & & 0.6520 \\
\hline & & & & $(0.4830)$ \\
\hline \multirow[t]{2}{*}{$\triangle N P L_{i, t}$} & $0.2182 * * *$ & $0.2094 * * *$ & $0.2112 * * *$ & $0.2150 * * *$ \\
\hline & $(0.0441)$ & $(0.0578)$ & $(0.0547)$ & $(0.0510)$ \\
\hline \multirow[t]{2}{*}{$\triangle N P L_{i, t-1}$} & $-0.0131 * * *$ & $-0.0133 * * *$ & $-0.0132 * * *$ & $-0.0133 * * *$ \\
\hline & $(0.0019)$ & $(0.0017)$ & $(0.0018)$ & $(0.0018)$ \\
\hline \multirow[t]{2}{*}{$\triangle N P L_{i, t-2}$} & $-0.0000 *$ & -0.0000 & -0.0000 & -0.0000 \\
\hline & $(0.0000)$ & $(0.0000)$ & $(0.0000)$ & $(0.0000)$ \\
\hline Observations & 21,016 & 21,016 & 21,016 & 21,016 \\
\hline R-squared & 0.091 & 0.091 & 0.091 & 0.090 \\
\hline Adjusted R-squared & 0.0875 & 0.0875 & 0.0877 & 0.0872 \\
\hline
\end{tabular}

This table reports OLS coefficient estimates of the model $\triangle N P L_{i, t+1}=\beta_{0}+\beta_{1} \times$ Instrument $_{c, t}+\beta_{2} \times \Delta N P L_{i, t}+\beta_{3} \times \Delta N P L_{i, t-1}+\beta_{4} \times \Delta N P L_{i, t-2}+\epsilon_{i, t}$, using the four choices of Instrument I,$t$. Regressions include year, country, and bank-type fixed effects. Country level clustered standard errors are reported in parentheses. ${ }^{* * *},{ }^{* *}$, and ${ }^{*}$ indicate statistical significance levels of $p<0.01, p<0.5$, and $p<0.1$, respectively. Variables are described in Appendix A 
Table 1.12: Defense Innovations, Deficits, and Loan Loss Provisions

\begin{tabular}{|c|c|c|c|}
\hline & \multicolumn{3}{|c|}{ Dep. variable $=l l p_{i, t}$} \\
\hline & (1) & (2) & (3) \\
\hline \multirow[t]{2}{*}{ Deficit $_{c, t}$} & $0.0760 * * *$ & $0.0766 * * *$ & $0.0759 * * *$ \\
\hline & $(0.0233)$ & $(0.0237)$ & $(0.0242)$ \\
\hline \multirow[t]{2}{*}{$\operatorname{Res} A R(1)_{c, t}$} & 0.1096 & & \\
\hline & $(0.1781)$ & & \\
\hline \multirow[t]{2}{*}{$\operatorname{Res} A R(2)_{c, t}$} & \multicolumn{3}{|c|}{0.1354} \\
\hline & \multicolumn{3}{|c|}{$(0.2111)$} \\
\hline \multirow[t]{2}{*}{$\operatorname{ResAR}(3)_{c, t}$} & & & 0.2103 \\
\hline & & & $(0.2313)$ \\
\hline \multirow[t]{2}{*}{$\% \Delta$ PerCapitaGDP $P_{c, t}$} & $-0.0121 *$ & $-0.0120 *$ & $-0.0120 * *$ \\
\hline & $(0.0063)$ & $(0.0062)$ & $(0.0058)$ \\
\hline \multirow[t]{2}{*}{ Ebllp $_{i, t}$} & $0.0776 * * *$ & $0.0776 * * *$ & $0.0775 * * *$ \\
\hline & $(0.0150)$ & $(0.0150)$ & $(0.0151)$ \\
\hline \multirow[t]{2}{*}{$\triangle N P L_{i, t+1}$} & -0.0055 & -0.0056 & -0.0057 \\
\hline & $(0.0239)$ & $(0.0239)$ & $(0.0240)$ \\
\hline \multirow[t]{2}{*}{$\triangle N P L_{i, t}$} & $0.2853 * * *$ & $0.2855 * * *$ & $0.2859 * * *$ \\
\hline & $(0.0231)$ & $(0.0234)$ & $(0.0236)$ \\
\hline \multirow[t]{2}{*}{$\triangle N P L_{i, t-1}$} & 0.0036 & 0.0037 & 0.0037 \\
\hline & $(0.0032)$ & $(0.0032)$ & $(0.0032)$ \\
\hline \multirow[t]{2}{*}{$\triangle N P L_{i, t-2}$} & $-0.0001 * * *$ & $-0.0001 * * *$ & $-0.0001 * * *$ \\
\hline & $(0.00004)$ & $(0.00004)$ & $(0.00004)$ \\
\hline \multirow[t]{2}{*}{ Size $_{i, t-1}$} & 0.0002 & 0.0002 & 0.0003 \\
\hline & $(0.0004)$ & $(0.0004)$ & $(0.0004)$ \\
\hline \multirow[t]{2}{*}{$C A P_{i, t-1}$} & 0.0114 & 0.0114 & 0.0114 \\
\hline & $(0.0072)$ & $(0.0072)$ & $(0.0072)$ \\
\hline Observations & 18,771 & 18,771 & 18,769 \\
\hline R-squared & 0.3225 & 0.3225 & 0.3226 \\
\hline Adjusted R-squared & 0.3197 & 0.3197 & 0.3198 \\
\hline
\end{tabular}

This table reports OLS coefficient estimates of the model $l l p_{i, t}=$ $\Lambda \cdot X_{i, t}+\gamma_{1} \times \% \Delta$ PerCapitaGDP $P_{c, t}+\gamma_{2} \times$ Deficit $_{c, t}+\gamma_{3} \times \operatorname{ResAR}(L)_{c, t}+$ $\epsilon_{i, t}$, for $L=1,2,3$. Regressions include year, country, and banktype fixed effects. Country level clustered standard errors are reported in parentheses. ${ }^{* * *}, * *$, and ${ }^{*}$ indicate statistical significance levels of $p<0.01, p<0.5$, and $p<0.1$, respectively. Variables are described in Appendix $\mathrm{A}$ 
Last, I turn my attention to investigating what contemporaneous and future economic effects are followed by shocks to defense spending in my sample of 47 countries. While prior research has shown different real effects arising from military spending, including economic output in periods of slack and employment growth (Hooker and Knetter, 1997; Owyang, Ramey, and Zubairy, 2013; Ramey and Zubairy, 2018), more analyses must be done to understand how such results are generalized to this large set of countries. To gauge the effects on governments' deficits and real economic output, I estimate Jordà (2005) local projections (LP's) using serial variation in deficit from $t$ to $t+1$ (i.e., $\left.\Delta D e f_{c, t+1} \equiv D e f_{c, t+1}-D e f_{c, t}\right):$

$$
\begin{aligned}
\text { Deficit }_{c, t+h}-\text { Deficit }_{c, t}= & \beta_{0}^{\text {Deficit }(h)}+\beta_{\text {Def }}^{\text {Deficit }(h)} \times \Delta \text { Def }_{c, t+1}+\beta_{1}^{\text {Deficit }(h)} \times \Delta \text { Deficit }_{c, t}+ \\
& +\beta_{2}^{\text {Deficit }(h)} \times \Delta^{\log }\left(G D P P C_{c, t}\right)+\beta_{3}^{\text {Deficit }(h)} \times \Delta^{\log }\left(\text { GDPPC }_{c, t-1}\right)+ \\
& +a_{c}^{\text {Deficit }(h)}+z_{t}^{\text {Deficit }(h)}+\epsilon_{c, t}^{\text {Deficit }(h)} \\
\log \left(\frac{G D P P C_{c, t+h}}{G D P P C_{c, t}}\right)= & \beta_{0}^{G D P P C(h)}+\beta_{D e f}^{G D P C(h)} \times \Delta D e f_{c, t+1}+\beta_{1}^{G D P P C(h)} \times \Delta D e f i c i t_{c, t}+ \\
& +\beta_{2}^{G D P P C(h)} \times \Delta^{\log }\left(G D P P C_{c, t}\right)+\beta_{3}^{G D P P C(h)} \times \Delta^{\log }\left(G D P P C_{c, t-1}\right)+ \\
& +a_{c}^{G D P P C(h)}+z_{t}^{G D P P C(h)}+\epsilon_{c, t}^{G D P P C(h)}
\end{aligned}
$$

where $G D P P C_{c, t}$ is the nominal GDP per capita, $\Delta^{\log }\left(G D P P C_{c, t}\right) \equiv$ $\log \left(\frac{G D P P C_{c, t}}{G D P P C_{c, t-1}}\right)$ and $h=1,2, \ldots, H$. Country and year fixed effects are included in all LP estimates and standard errors are clustered at the country level.

The sequence of coefficients $\beta_{D e f}^{D e f i c i t(h)}$ and $\beta_{D e f}^{G D P P C(h)}$ trace out the response of the countries' deficits and GDP per capita to a one-percent variation in the countries' defense spending as a fraction of their respective GDP. ${ }^{24}$ Results are plotted

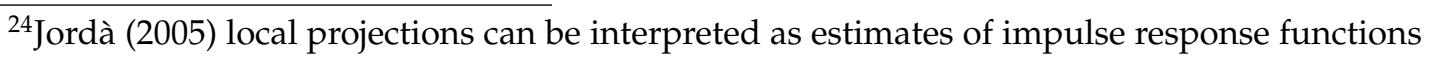
that do not rely on any VAR specification characterizing the data-generating process of the en-
} 
in Figure 1.8, including average responses and 95\% confidence intervals. ${ }^{25}$

The response of deficits to defense spending (upper plot) suggests an overshoot in the levels of deficits contemporaneous to the event measured by $D e f_{c, t+1}$, which happens by construction and is consistent with the relevance of the instrument. Deficits tend to revert after two or three years, which is consistent with the argument that most of the fluctuations in deficits are primarily due to fluctuations in defense spending (Ramey, 2011). The response of GDP per capita to defense spending (lower plot) suggests that, on average, positive shocks to defense spending are not associated with economic stimuli for the 47 countries of my sample.

dogenous macroeconomic variables. For the sole purpose of this analysis, I do not restrict my sample to the period from 1996 to 2014, but rather include all valid observations of macroeconomic variables for the set of 47 countries considered in all my previous results.

${ }^{25}$ I normalize the impulse response coefficients $\beta_{D e f}^{D e f i c i t(h)}$ and $\beta_{D e f}^{G D P P C(h)}$ by dividing them by 100 , so that estimates represent the average response to a $1 \%$ increase in defense spending. Coefficients for $h=0$ are normalized to 1 since the response measured refers to a shock to defense spending that occurs between years $t$ and $t+1$. 

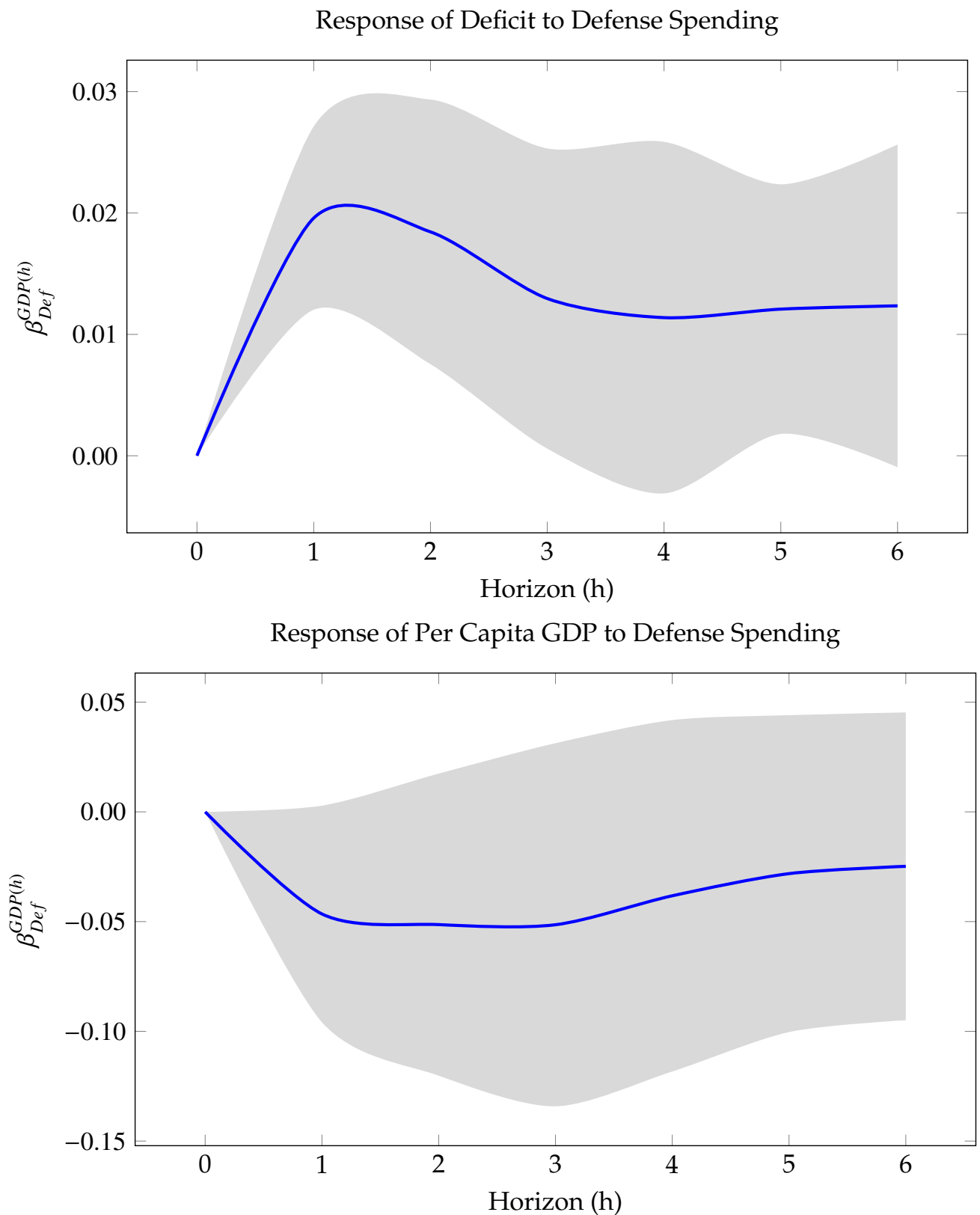

Impulse response of Deficit (upper plot) and Per Capita GDP to Defense Spending estimated using Jordà (2005) Local Projections, including 95\% confidence intervals.

Figure 1.8: Jordà (2005) Local Projections 


\subsection{Conclusion}

In this essay I propose and find evidence consistent with a new channel in which banks' loan loss provisions are affected by the country's fiscal policy through the interaction of the financial reporting incentives bank managers have when setting up their provisions for future credit losses with the direct effect of governments' deficits to the strength of government guarantees granted to the banks.

Using a large sample of banks from 47 different countries I find that the country's overall fiscal deficit is positively associated with the levels of loan loss provisions reported by the banks, and that this overall effect is moderated by the country's debt-to-GDP ratio. The empirical relationship between governments' fiscal deficits and banks' loan loss provisions is statistically stronger and more economically relevant than the business cycle effect extensively documented in the literature, and robust to different subsamples and the inclusion of additional macroeconomic controls. To strengthen the internal validity of my results being consistent with a direct channel of fiscal policy, I identify fiscal shocks by estimating innovations to defense and military expenditures of different governments over my sample period and use such shocks as instruments for countries' fiscal deficits, showing that governments' deficits are positively associated with banks' loan loss provisions.

While empirically consistent with a direct channel of fiscal policy, my results are, nevertheless, subject to different caveats. First, as the intervening variables representing the direct channel (i.e., the strength of government guarantees and managers' assessment of tail risk properties of banks' assets) are not directly measurable, empirical tests can at best provide indirect evidence of the direct chan- 
nel. Second, as a typical characteristic of IV settings, the exclusion restriction is an empirical challenge for which evidence is hardly conclusive. While the identification of fiscal shocks bolsters the argument that the effect is driven by fiscal decisions made due to strategic or geopolitical factors mostly unrelated to business cycles, it is also consistent with indirect channel effects of fiscal policy not captured by the business cycle proxy in reduced-form specifications, or even reflected in managers' expectations that levels of deficits are associated with the credibility of possible fiscal policy stimuli that affect the business cycle in the future.

Altogether, my findings contribute to the finance and banking literature by demonstrating that fiscal deficit - a major factor of the political economy of countries - represents an important state variable for banks' credit risk and ultimately affects their financial reporting behavior. 


\section{APPENDIX A}

\section{VARIABLE DEFINITIONS}

Table A.1: Variable Definitions

\begin{tabular}{|c|c|c|}
\hline \multicolumn{3}{|c|}{ Bank-specific Variables } \\
\hline Variable & Description & Source \\
\hline$l l p_{i, t}$ & Bank $i^{\prime}$ s loan loss provision for year $t$ scaled by lagged total loans & Bankscope \\
\hline Ebllp $_{i, t}$ & $\begin{array}{l}\text { Bank } i^{\prime} \text { s earnings before loan loss provisions and taxes for year } t \\
\text { scaled by lagged total loans }\end{array}$ & Bankscope \\
\hline$\triangle N P L_{i, t}$ & Change in non-performing loans scaled by lagged total assets & Bankscope \\
\hline$C A P_{i, t}$ & Bank $i^{\prime}$ s total equity by total assets capital ratio at year $t$ & Bankscope \\
\hline Size $_{i, t}$ & $\begin{array}{l}\text { Natural logarithm of bank } i^{\prime} \text { s dollar-nominated total assets } \\
\text { measured in millions of USD at year } t \text {. }\end{array}$ & Bankscope \\
\hline \multicolumn{3}{|c|}{ Macro and Aggregate Variables } \\
\hline Variable & Description & Source \\
\hline$\% \Delta$ PerCapitaGDP $P_{c, t}$ & $\begin{array}{l}\text { Percent (annual) variation of Per Capita GDP for a given country } c \\
\text { — in our empirical specifications related to the country in which a } \\
\text { given bank } i \text { is domiciled. }\end{array}$ & World Bank \\
\hline Deficit $_{c, t}$ & $\begin{array}{l}\text { Fiscal Deficit, i.e., Government Expenditures minus Government } \\
\text { Revenues, scaled by the country's GDP for a given country-year }(c, t)\end{array}$ & IMF \\
\hline DebttoGDP $P_{c, t}$ & $\begin{array}{l}\text { Government's public debt scaled by the country's GDP for a given } \\
\text { country-year }(c, t)\end{array}$ & World Bank \\
\hline
\end{tabular}


Table A.1 - continued from the previous page

\begin{tabular}{|c|c|c|}
\hline Variable & Description & Source \\
\hline$\Delta$ Unemp $_{c, t}$ & $\begin{array}{l}\text { Change in unemployment rate from year } t-1 \text { to } t \text { for a given } \\
\text { country } c\end{array}$ & World Bank \\
\hline$\% \Delta R E_{c, t}$ & $\begin{array}{l}\text { Percent change in average Real Estate prices from year } t-1 \text { to } t \text { for a } \\
\text { given country } c\end{array}$ & Various sources \\
\hline EYear $_{c, t}$ & $\begin{array}{l}\text { Dummy variable that takes the value one if a major/general election } \\
\text { took place in country-year }(c, t) \text { and zero otherwise. }\end{array}$ & $\begin{array}{l}\text { Hand-collected } \\
\text { (various } \\
\text { sources) }\end{array}$ \\
\hline CBIndep ${ }_{c}$ & Alesina and Summers (1993) Index of Central Bank Independence & $\begin{array}{l}\text { Alesina and } \\
\text { Summers (1993) }\end{array}$ \\
\hline$E P U_{t}^{3 M-A v g, \text { Global }}$ & $\begin{array}{l}\text { Average monthly Global Economic Policy Uncertainty Index } \\
\text { proposed by Baker et al. (2016) over the last three months of year } t\end{array}$ & EPU Website \\
\hline$E P U_{t}^{12 M-A v g, G l o b a l}$ & $\begin{array}{l}\text { Average monthly Global Economic Policy Uncertainty Index } \\
\text { proposed by Baker et al. (2016) over the twelve months of year } t\end{array}$ & EPU Website \\
\hline
\end{tabular}


APPENDIX B

\section{ADDITIONAL ANALYSES}

In this Appendix section, I marshal different pieces of evidence to dispute alternative explanations that associations between deficits and banks' loan loss provisions arise from business cycles or other unobserved macroeconomic variables.

\section{B.1 Lagged Effects of Fiscal Policy and Business Cycles}

The results reported in Tables 1.5 and 1.8 are consistent with a joint effect of business cycles and governments' fiscal policy on banks' loan loss provisions, the latter being empirically stronger and moderated by how well positioned the government is to either provide fiscal backing to the country's banks (direct channel) or to interfere in the business cycle (indirect channel). However, these estimates still do not disentangle the economic interactions between business cycles and fiscal policy. Indeed, fiscal policy is, together with monetary policy, a key instrument used by governments to conduct macroeconomic stabilization policy. Differently put, not only are fiscal policy actions taken as a consequence of fluctuations in the real economy but they are also expected to have their own impact on business cycles.

From an empirical standpoint, one should expect both $\% \triangle P e r C a p i t a G D P_{c, t}$ and Deficit $t_{c, t}$ to be affected by lagged terms of $\% \Delta$ PerCapitaGDP $P_{c, t}$ and Deficit $t_{c, t}$ by both construction and policy response. To alleviate concerns that serial correlations representing the joint responses of fiscal policy and business cycles could be driving my main results, I augment the loan loss provision model of equation 
(1.4) to include the lagged terms of $\% \Delta$ PerCapitaGDP $P_{c, t-1}, \% \Delta$ PerCapitaGDP $P_{c, t-2}$, Deficit $_{c, t-1}$ and Deficit $t_{c, t-2}$ as follows. As before, I also include the terms $\triangle N P L_{i, t+1} \times \% \triangle P \operatorname{PerCapitaGDP} P_{c, t}$ and $\triangle N P L_{i, t+1} \times$ Deficit $_{c, t}$ in the last specification to analyze the effect on the timeliness of the loan loss provision.

$$
\begin{aligned}
\text { ll }_{i, t}= & \alpha+\gamma_{1} \times \% \Delta \text { PerCapitaGDP } \\
& +\gamma_{c, t} \times \% \Delta \text { PerCapitaGDP }{ }_{c, t-2}+ \\
& +\gamma_{4} \times \text { Deficit }_{c, t}+\gamma_{5} \times \text { Deficit }_{c, t-1}+\gamma_{6} \times \text { Deficit }_{c, t-2}+ \\
& +\gamma_{7} \times \Delta N P L_{i, t+1} \times \% \Delta \text { PerCapitaGDP } \\
c, t & +\gamma_{8} \times \Delta N P L_{i, t+1} \times \text { Deficit }_{c, t}+ \\
& +\lambda_{1} \times \text { Ebll }_{i, j}+\lambda_{2} \times \Delta N P L_{i, t+1}+\lambda_{3} \times \Delta N P L_{i, t}+\lambda_{4} \times \Delta N P L_{i, t-1}+ \\
& +\lambda_{5} \times \Delta N P L_{i, t-2}+\lambda_{6} \times C A P_{i, t-1}+\lambda_{7} \times \text { Size }_{i, t-1}+\epsilon_{i, t}
\end{aligned}
$$

Coefficient estimates are reported in Table B.1. Under all different empirical specifications, the coefficient estimates of the contemporaneous fiscal policy term Deficit $t_{c, t}$ are positive and statistically significant at the $1 \%$ confidence level. Moreover, the introduction of lagged terms of fiscal policy does not subsume the economic significance of the contemporaneous coefficient. For the business cycle effect, while all estimates of the coefficient of $\% \triangle P \operatorname{Per}$ CapitaGDP $P_{c, t}$ are negative, both statistical significance and magnitude decrease when lagged terms of fiscal policy and business cycles are introduced. 
Table B.1: Fiscal Policy and Business Cycles — Result Including Lagged Terms

\begin{tabular}{|c|c|c|c|c|}
\hline & \multicolumn{4}{|c|}{ Dep. variable $=l l p_{i, t}$} \\
\hline & (1) & (2) & (3) & (4) \\
\hline$\% \Delta$ PerCapitaGDP $P_{c, t}$ & $\begin{array}{c}-0.0107 * * \\
(0.0047)\end{array}$ & $\begin{array}{c}-0.0142 * * \\
(0.0056)\end{array}$ & $\begin{array}{r}-0.0057 \\
(0.0035)\end{array}$ & $\begin{array}{c}-0.0069 * * \\
(0.0033)\end{array}$ \\
\hline$\% \Delta$ PerCapitaGDP $P_{c, t-1}$ & $\begin{array}{r}-0.0031 \\
(0.0063)\end{array}$ & $\begin{array}{r}-0.0008 \\
(0.0058)\end{array}$ & & $\begin{array}{r}-0.0002 \\
(0.0047)\end{array}$ \\
\hline$\% \Delta$ PerCapitaGDP $P_{c, t-2}$ & & $\begin{array}{c}-0.0114 * * \\
(0.0044)\end{array}$ & & $\begin{array}{c}-0.0118 * * \\
(0.0047)\end{array}$ \\
\hline Deficit $_{c, t}$ & $\begin{array}{l}0.0838 * * * \\
(0.0261)\end{array}$ & $\begin{array}{l}0.0725 * * * \\
(0.0201)\end{array}$ & $\begin{array}{l}0.1014 * * * \\
(0.0280)\end{array}$ & $\begin{array}{l}0.1035 * * * \\
(0.0272)\end{array}$ \\
\hline Deficit ${ }_{c, t-1}$ & $\begin{array}{r}-0.0129 \\
(0.0127)\end{array}$ & & $\begin{array}{c}-0.0407 * * \\
(0.0188)\end{array}$ & $\begin{array}{c}-0.0445 * * \\
(0.0184)\end{array}$ \\
\hline Deficit $_{c, t-2}$ & & & $\begin{array}{c}0.0225 \\
(0.0222)\end{array}$ & $\begin{array}{c}0.0159 \\
(0.0183)\end{array}$ \\
\hline Ebllp $_{i, t}$ & $\begin{array}{l}0.0777 * * * \\
(0.0152)\end{array}$ & $\begin{array}{l}0.0782 * * * \\
(0.0149)\end{array}$ & $\begin{array}{l}0.0772 * * * \\
(0.0156)\end{array}$ & $\begin{array}{l}0.0778 * * * \\
(0.0154)\end{array}$ \\
\hline$\triangle N P L_{i, t+1}$ & $\begin{array}{r}-0.0050 \\
(0.0234)\end{array}$ & $\begin{array}{r}-0.0044 \\
(0.0234)\end{array}$ & $\begin{array}{c}0.0006 \\
(0.0231)\end{array}$ & $\begin{array}{c}0.0010 \\
(0.0228)\end{array}$ \\
\hline$\triangle N P L_{i, t}$ & $\begin{array}{l}0.2862 * * * \\
(0.0229)\end{array}$ & $\begin{array}{l}0.2874 * * * \\
(0.0226)\end{array}$ & $\begin{array}{l}0.2902 * * * \\
(0.0210)\end{array}$ & $\begin{array}{l}0.2893 * * * \\
(0.0215)\end{array}$ \\
\hline$\triangle N P L_{i, t-1}$ & $\begin{array}{c}0.0034 \\
(0.0030)\end{array}$ & $\begin{array}{c}0.0035 \\
(0.0031)\end{array}$ & $\begin{array}{c}0.0034 \\
(0.0029)\end{array}$ & $\begin{array}{c}0.0033 \\
(0.0029)\end{array}$ \\
\hline$\triangle N P L_{i, t-2}$ & $\begin{array}{c}0.0218 * \\
(0.0109)\end{array}$ & $\begin{array}{c}-0.0001 \text { *** } \\
(0.0000)\end{array}$ & $\begin{array}{l}0.0213 * * \\
(0.0105)\end{array}$ & $\begin{array}{l}0.0203 * * \\
(0.0099)\end{array}$ \\
\hline$C A P_{i, t-1}$ & $\begin{array}{c}0.0122 * \\
(0.0071)\end{array}$ & $\begin{array}{c}0.0109 \\
(0.0075)\end{array}$ & $\begin{array}{c}0.0127 * \\
(0.0068)\end{array}$ & $\begin{array}{c}0.0123 * \\
(0.0071)\end{array}$ \\
\hline $\operatorname{Size}_{i, t-1}$ & $\begin{array}{c}0.0003 \\
(0.0004)\end{array}$ & $\begin{array}{c}0.0003 \\
(0.0004)\end{array}$ & $\begin{array}{c}0.0003 \\
(0.0004)\end{array}$ & $\begin{array}{c}0.0003 \\
(0.0004)\end{array}$ \\
\hline Observations & 18,326 & 18,800 & 17,725 & 17,725 \\
\hline R-squared & 0.325 & 0.326 & 0.325 & 0.328 \\
\hline Adjusted R-squared & 0.322 & 0.323 & 0.322 & 0.325 \\
\hline
\end{tabular}

This table reports OLS coefficient estimates of different specifications of the model $l l p_{i, t}=\Lambda \cdot X_{i, t}+\gamma_{1} \times \% \Delta$ PerCapitaGDP $P_{c, t}+\gamma_{2} \times \% \Delta$ PerCapitaGDP $P_{c, t-1}+\gamma_{3} \times$ $\% \Delta$ PerCapitaGDP $P_{c, t-2}+\gamma_{4} \times$ Deficit $_{c, t}+\gamma_{5} \times$ Deficit $_{c, t-1}+\gamma_{6} \times$ Deficit $_{c, t-2}+\epsilon_{i, t}$ for the whole sample of banks from 47 countries. Regressions include year, country, and bank-type fixed effects. Country level clustered standard errors are reported in parentheses. ${ }^{* * *}, * *$, and ${ }^{*}$ indicate statistical significance levels of $p<0.01, p<0.5$, and $p<0.1$, respectively. Variables are described in Appendix $\mathrm{A}$ 


\section{B.2 Controlling for Additional Macroeconomic and Geopoliti-}

\section{cal Variables}

The empirical results presented in Table B.1 suggest that the relationship between fiscal policy and banks' financial reporting is driven by contemporaneous states of governments' finances, hence alleviating concerns that my empirical results reflect spurious relations between two macroeconomic variables whose time-series properties are naturally linked. Nevertheless, cycles of real economic activity are not only represented by the variation in $\% \triangle P$ erCapitaGDP $P_{c, t}$ but are differentially observed in other aggregate measures. The same argument applies to the budgetary representation of governments' fiscal policy. Fiscal policy is one component of the broader construct of "economic policy" which ultimately affects the likelihood, credibility, and effectiveness associated with government guarantees. In other words, the economic effects of fiscal policy and business cycles are naturally intertwined with effects arising from other variables.

To investigate whether my main results hold when controlling for different dimensions of macroeconomic activity and policy which are potentially correlated with Deficit $t_{c, t}$ and $\% \triangle$ PerCapitaGDP $P_{c, t}$ I augment model (1.3) by including different country-level variables.

Regarding business cycles, I include (i) $\Delta U n e m p_{c, t}$ (variation in the unemployment rate of country $c$ between years $t-1$ and $t$, obtained from the World Bank database) and (ii) $\% \Delta R E_{c, t}$ (return on average real estate prices of country $c$ between years $t-1$ and $t$, obtained from multiple sources) ${ }^{1}$

\footnotetext{
${ }^{1}$ Data is collected from different databases for different countries, including the OECD and government agencies. Regression estimates including $\% \Delta R E_{c, t}$ naturally have less observations
} 
To account for country-specific dimensions of political economy uncertainty, I consider (iii) EYear ${ }_{c, t}$ (and EYear ${ }_{c, t+1}$ ) - dummy variables indicating whether a general election will take place in the current (and following) year in country $c i^{2}$ and (iv) CBInde $p_{c}$ - the index of Central Bank Independence (proposed by Alesina and Summers, 1993), representing an important component of monetary policy and banking supervision.

Last, to control for worldwide political economy uncertainty, I consider two variants of the Economic Policy Uncertainty Index proposed by Baker, Bloom, and Davis (2016). ${ }^{3}$ Their uncertainty index is computed monthly for 20 different nations and for the global level by considering the newspaper coverage of policy-related economic uncertainty, the number of federal tax code provisions set to expire in future years, and the forecast dispersion of professional economists. As my analyses are conducted with the time granularity of years I construct the year-specific measures $E P U_{t}^{12 M-A v g, G l o b a l}$ and $E P U_{t}^{3 M-A v g, G l o b a l}$, respectively representing the 12-month average of the monthly Global Economic Policy Uncertainty Index for a given year and the fourth quarter (Q.4) average of the same index. ${ }^{4}$

Table B.2 reports the coefficient estimates for the augmented specifications of model (1.3). For didactic purposes, estimates of bank-specific coefficients $(\Lambda)$ are omitted. Specifications (1-3) include only proxies for business cycles, given the lack of real estate prices or indexes for some developing countries.

${ }^{2}$ For presidential regimes (U.S., Brazil, Mexico, etc.) only the presidential election is considered. For countries with parliamentary systems (U.K., India, etc.) general parliamentary and presidential elections are taken into consideration. The forward-looking dummy is included because political uncertainty is possibly incorporated by economic agents in anticipation of a power transition.

${ }^{3}$ I thank Scott Baker, Nick Bloom, and Steven Davis for making the Economic Policy Uncertainty Index publicly available at http://www.policyuncertainty.com/

${ }^{4}$ The intuition to consider the average of the last three months in a year is that uncertainty over this period should affect preparers of banks' annual reports more strongly than the uncertainty over earlier quarters. 
whereas specifications (4-7) consider only political economy proxies. Consistent with my prior findings that fiscal policy has a statistically and economically stronger effect than business cycles on banks' reporting choices, I find estimates of Deficit $t_{c, t}$ for all eight specifications to be positive and statistically significant ( $\mathrm{p}$-values $<1 \%$ ) and their magnitudes to be minimally affected by the inclusion of different covariates. Coefficients of $\% \triangle$ PerCapitaGDP $P_{c, t}$, however, are gradually subsumed as other business cycle proxies are included. 
Table B.2: Fiscal Policy and Business Cycles — Additional Controls

\begin{tabular}{|c|c|c|c|c|c|c|c|c|}
\hline & \multicolumn{8}{|c|}{ Dep. variable $=l l p_{i, t}$} \\
\hline & \multicolumn{3}{|c|}{ Business Cycle } & \multicolumn{4}{|c|}{ Political Economy } & \multirow{2}{*}{$\begin{array}{l}\text { All } \\
(8)\end{array}$} \\
\hline & (1) & (2) & (3) & $(4)$ & (5) & (6) & (7) & \\
\hline$\% \Delta$ PerCapitaGDP $P_{c, t}$ & $\begin{array}{c}-0.0093 * \\
(0.0052)\end{array}$ & $\begin{array}{r}-0.0156 \\
(0.0091)\end{array}$ & $\begin{array}{c}-0.0085 \\
(0.0084)\end{array}$ & $\begin{array}{c}-0.0127 * * \\
(0.0052)\end{array}$ & $\begin{array}{r}-0.0159 \\
(0.0121)\end{array}$ & $\begin{array}{c}-0.0127 * * \\
(0.0057)\end{array}$ & $\begin{array}{r}-0.0173 \\
(0.0114)\end{array}$ & $\begin{array}{r}-0.0067 \\
(0.0096)\end{array}$ \\
\hline$\Delta$ Unemp $_{c, t}$ & $\begin{array}{l}0.0019 * * \\
(0.0006)\end{array}$ & & $\begin{array}{l}0.0020 * * \\
(0.0007)\end{array}$ & & & & & $\begin{array}{l}0.0021 * * \\
(0.0008)\end{array}$ \\
\hline$\% \Delta R E_{c, t}$ & & $\begin{array}{c}-0.0021 \\
(0.0016)\end{array}$ & $\begin{array}{c}-0.0019 * \\
(0.0011)\end{array}$ & & & & & $\begin{array}{r}-0.0018 \\
(0.0010)\end{array}$ \\
\hline Deficit $_{c, t}$ & $\begin{array}{l}0.0722 * * \\
(0.0216)\end{array}$ & $\begin{array}{cc}k * 0755 * * * \\
(0.0250)\end{array}$ & $\begin{array}{c}* 0.0835 * * * \\
(0.0246)\end{array}$ & $\begin{array}{l}0.0777 * * \\
(0.0225)\end{array}$ & $\begin{array}{c}* 0.0917 * * \\
(0.0216)\end{array}$ & $\begin{array}{c}* 0.0786 * * \\
(0.0229)\end{array}$ & $\begin{array}{c}* 0.0902 * * * \\
(0.0230)\end{array}$ & $\begin{array}{c}* 0.108 * * * \\
(0.0226)\end{array}$ \\
\hline EYear $_{c, t}$ & & & & $\begin{array}{r}-0.0006 \\
(0.0005)\end{array}$ & & & $\begin{array}{c}-0.0009 \\
(0.0006)\end{array}$ & $\begin{array}{r}-0.0000 \\
(0.0006)\end{array}$ \\
\hline EYear $_{c, t+1}$ & & & & $\begin{array}{r}-0.0013 \\
(0.0008)\end{array}$ & & & $\begin{array}{c}-0.0019 * * \\
(0.0007)\end{array}$ & $\begin{array}{c}-0.0014 * * \\
(0.0004)\end{array}$ \\
\hline CBIndep ${ }_{c}$ & & & & & $\begin{array}{c}-0.0011 \\
(0.0007)\end{array}$ & & $\begin{array}{c}-0.0011 \\
(0.0007)\end{array}$ & $\begin{array}{c}-0.0017 * * \\
(0.0007)\end{array}$ \\
\hline$E P U_{t}^{12 M-A v g, \text { Global }}$ & & & & & & $\begin{array}{c}-0.0003 * * \\
(0.0001)\end{array}$ & $\begin{array}{c}*-0.0003 * * * \\
(0.0001)\end{array}$ & $\begin{array}{c}*-0.0003 * * \\
(0.0001)\end{array}$ \\
\hline$E P U_{t}^{3 M-A v g, \text { Global }}$ & & & & & & $\begin{array}{l}0.0003 * * \\
(0.0001)\end{array}$ & $\begin{array}{c}* 0.0003 * * * \\
(0.0001)\end{array}$ & $\begin{array}{c}* 0.0003 * * \\
(0.0000)\end{array}$ \\
\hline Observations & 18,800 & 15,439 & 15,439 & 18,800 & 14,616 & 18,477 & 14,343 & 14,140 \\
\hline R-squared & 0.332 & 0.285 & 0.296 & 0.324 & 0.243 & 0.322 & 0.245 & 0.257 \\
\hline Adjusted R-squared & 0.330 & 0.283 & 0.293 & 0.321 & 0.241 & 0.319 & 0.242 & 0.255 \\
\hline
\end{tabular}

This table reports OLS coefficient estimates of different specifications of the modell $p_{i, t}=\Gamma \cdot M_{c, t}+\Lambda \cdot X_{i, t}+\epsilon_{i, t}$ augmented by different proxies of business cycle and political economy. Coefficient estimates of bankspecific covariates $\left(X_{i, t}\right)$ are omitted for presentation purposes. Regressions include year, country, and bank-type fixed effects. Country level clustered standard errors are reported in parentheses. ${ }^{* * *}, * *$, and * indicate statistical significance levels of $p<0.01, p<0.5$, and $p<0.1$, respectively. Variables are described in Appendix $\mathrm{A}$ 


\section{BIBLIOGRAPHY}

Viral Acharya, Itamar Drechsler, and Philipp Schnabl. A Pyrrhic Victory? Bank Bailouts and Sovereign Credit Risk. The Journal of Finance, 69(6):2689-2739, 2014.

Viral V Acharya and Stephen G Ryan. Banks Financial Reporting and Financial System Stability. Journal of Accounting Research, 54(2):277-340, 2016.

Viral V Acharya, Deniz Aginer, and A Joseph Warburton. The End of Market Discipline? Investor Expectations of Implicit Government Guarantees. Available at SSRN 1961656, 2016.

Anwer S Ahmed, Carolyn Takeda, and Shawn Thomas. Bank Loan Loss Provisions: A Reexamination of Capital Management, Earnings Management and Signaling Effects. Journal of Accounting and Economics, 28(1):1-25, 1999.

Alberto Alesina and Lawrence H Summers. Central Bank Independence and Macroeconomic Performance: Some Comparative Evidence. Journal of Money, Credit and Banking, 25(2):151-162, 1993.

Franklin Allen, Elena Carletti, Itay Goldstein, and Agnese Leonello. Government Guarantees and Financial Stability. 2017.

Scott R Baker, Nicholas Bloom, and Steven J Davis. Measuring Economic Policy Uncertainty. The Quarterly Journal of Economics, 131(4):1593-1636, 2016.

Eliana Balla, Morgan J Rose, and Jessica Sackett Romero. Loan Loss Reserve Accounting and Bank Behavior. Richmond Fed Economic Brief, (Mar), 2012.

Matthew D Baron. Countercyclical Bank Equity Issuance. Available at SSRN 2902505, 2016. 
Mary E Barth, Javier Gómez Biscarri, Ron Kasznik, and Germán LópezEspinosa. Bank Earnings and Regulatory Capital Management Using Available for Sale Securities. 2016.

Anne Beatty and Scott Liao. Do delays in expected loss recognition affect banks' willingness to lend? Journal of Accounting and Economics, 52(1):1-20, 2011.

Anne Beatty and Scott Liao. Financial Accounting in the Banking Industry: A Review of the Empirical Literature. Journal of Accounting and Economics, 58(2): 339-383, 2014.

Anne Beatty, Sandra L Chamberlain, and Joseph Magliolo. Managing Financial Reports of Commercial Banks: The Influence of Taxes, Regulatory Capital, and Earnings. Journal of Accounting Research, pages 231-261, 1995.

William Beaver, Carol Eger, Stephen Ryan, and Mark Wolfson. Financial Reporting, Supplemental Disclosures, and Bank Share Prices. Journal of Accounting Research, pages 157-178, 1989.

William H Beaver and Ellen E Engel. Discretionary Behavior with Respect to Allowances for Loan Losses and the Behavior of Security Prices. Journal of Accounting and Economics, 22(1):177-206, 1996.

Antje Berndt, Hanno Lustig, and Şevin Yeltekin. How Does the US Government Finance Fiscal Shocks? American Economic Journal: Macroeconomics, 4(1):69$104,2012$.

Gauri Bhat, Stephen G Ryan, and Dushyantkumar Vyas. The Implications of Credit Risk Modeling for Banks' Loan Loss Provision Timeliness and Loan Origination Procyclicality. 2013. 
Jacob A Bikker and Paul AJ Metzemakers. Bank Provisioning Behaviour and Procyclicality. Journal of International Financial Markets, Institutions and Money, 15(2):141-157, 2005.

Olivier Blanchard and Roberto Perotti. An Empirical Characterization of the Dynamic Effects of Changes in Government Spending and Taxes on Output. The Quarterly Journal of Economics, 117(4):1329-1368, 2002.

Markus K Brunnermeier, Luis Garicano, Philip R Lane, Marco Pagano, Ricardo Reis, Tano Santos, David Thesmar, Stijn Van Nieuwerburgh, Dimitri Vayanos, et al. The Sovereign-Bank Diabolic Loop and ESBies. American Economic Review, Papers \& Proceedings, 2016.

Robert M Bushman and Christopher D Williams. Accounting Discretion, Loan Loss Provisioning, and Discipline of Banks Risk-taking. Journal of Accounting and Economics, 54(1):1-18, 2012.

Robert M Bushman and Christopher D Williams. Delayed Expected Loss Recognition and the Risk Profile of Banks. Journal of Accounting Research, 53(3):511$553,2015$.

Charles W Calomiris and Stephen H Haber. Fragile by Design: The Political Origins of Banking Crises and Scarce Credit. Princeton University Press, 2014.

Zhuo Chen, Andrea Y Lu, and Zhuqing Yang. Growing pains: International instability and equity market returns. Financial Management, 2016.

Julie H Collins, Douglas A Shackelford, and James M Wahlen. Bank Differences in the Coordination of Regulatory Capital, Earnings, and Taxes. Journal of Accounting Research, pages 263-291, 1995. 
Ricardo Correa, Kuan-hui Lee, Horacio Sapriza, and Gustavo A Suarez. Sovereign Credit Risk, Banks' Government Support, and Bank Stock Returns around the World. Journal of Money, Credit and Banking, 46(s1):93-121, 2014.

Manuela Dantas, Kenneth J Merkley, and Felipe Bastos G Silva. Government Guarantees and Banks' Earnings Management. Available at SSRN 2797697, 2018.

Mathias Dewatripont and Jean Tirole. Macroeconomic shocks and banking regulation. Journal of Money, Credit and Banking, 44(s2):237-254, 2012.

Douglas W Diamond and Philip H Dybvig. Bank Runs, Deposit Insurance, and Liquidity. Journal of Political economy, 91(3):401-419, 1983.

Douglas W Diamond and Raghuram G Rajan. Liquidity Risk, Liquidity Creation, and Financial Fragility: A Theory of Banking. Journal of Political Economy, 109(2):287-327, 2001.

Steven Erlanger. France Will Take Full NATO Membership Again, With Greater Military Role. The New York Times, Mar 2009. URL https://www.nytimes. com/2009/03/12/world/europe/12france.html1/.

Antonio Fatás and Ilian Mihov. The Effects of Fiscal Policy on Consumption and Employment: Theory and Evidence. 2001.

Antonio Fatás and Ilian Mihov. The Case for Restricting Fiscal Policy Discretion. The Quarterly Journal of Economics, 118(4):1419-1447, 2003.

José L Fillat and Judit Montoriol-Garriga. Addressing the Pro-cyclicality of Capital Requirements with a Dynamic Loan Loss Provision System. Federal Reserve Bank of Boston, Boston MA, 2010. 
Markus Fischer, Christa Hainz, Jörg Rocholl, and Sascha Steffen. Government Guarantees and Bank Risk Taking Incentives. 2014.

Mark J Flannery, Simon H Kwan, and Mahendrarajah Nimalendran. Market Evidence on the Opaqueness of Banking Firms Assets. Journal of Financial Economics, 71(3):419-460, 2004.

Ana Rosa Fonseca and Francisco González. Cross-country Determinants of Bank Income Smoothing by Managing Loan-loss Provisions. Journal of Banking E Finance, 32(2):217-228, 2008.

Jordi Galí, J David López-Salido, and Javier Vallés. Understanding the Effects of Government Spending on Consumption. Journal of the European Economic Association, 5(1):227-270, 2007.

Priyank Gandhi and Hanno Lustig. Size Anomalies in US Bank Stock Returns. The Journal of Finance, 70(2):733-768, 2015.

Priyank Gandhi, Hanno N Lustig, and Alberto Plazzi. Equity is Cheap for Large Financial Institutions: The International Evidence. NBER Working Paper. Also available at SSRN 2747307, 2016.

Günther Gebhardt and Zoltan Novotny-Farkas. Mandatory IFRS Adoption and Accounting Quality of European Banks. Journal of Business Finance $\mathcal{E}$ Accounting, 38(3-4):289-333, 2011.

Mary Brady Greenawalt and Joseph F Sinkey. Bank Loan-loss Provisions and the Income-smoothing Hypothesis: An Empirical Analysis, 1976-1984. Journal of Financial Services Research, 1(4):301-318, 1988.

Reint Gropp, Christian Gruendl, and Andre Guettler. The Impact of Public 
Guarantees on Bank Risk-taking: Evidence from a Natural Experiment. Review of Finance, page rft014, 2013.

Mark A Hooker and Michael M Knetter. The Effects of Military Spending on Economic Activity: Evidence from State Procurement Spending. Journal of Money, Credit, and Banking, pages 400-421, 1997.

Gabriel Jiménez, Steven Ongena, José-Luis Peydró, and Jesús Saurina. Macroprudential Policy, Countercyclical Bank Capital Buffers, and Credit Supply: Evidence from the Spanish Dynamic Provisioning Experiments. Journal of Political Economy, 125(6):2126-2177, 2017.

Òscar Jordà. Estimation and Inference of Impulse Responses by Local Projections. American economic review, 95(1):161-182, 2005.

Bryan T Kelly, Hanno Lustig, and Stijn Van Nieuwerburgh. Too-systemic-tofail: What Option Markets Imply About Sector-wide Government Guarantees. American Economic Review (forthcoming), 2016.

John Maynard Keynes. General Theory of Employment, Interest and Money. Atlantic Publishers \& Dist, 1937.

Emre Kilic, Gerald J Lobo, Tharindra Ranasinghe, and K Sivaramakrishnan. The Impact of SFAS 133 on Income Smoothing by Banks through Loan Loss Provisions. The Accounting Review, 88(1):233-260, 2012.

Luc Laeven and Giovanni Majnoni. Loan Loss Provisioning and Economic Slowdowns: Too Much, Too Late? Journal of Financial Intermediation, 12(2): 178-197, 2003.

Chi-Chun Liu and Stephen G Ryan. Income Smoothing over the Business Cycle: Changes in Banks' Coordinated Management of Provisions for Loan Losses 
and Loan Charge-offs from the pre-1990 Bust to the 1990s Boom. The Accounting Review, 81(2):421-441, 2006.

Bappa Majumdar. Government Raises Defence Budget After Mumbai Attacks. Reuters, Feb 2009. URL https://in.reuters.com/article / idINIndia-38045420090216.

Donald P Morgan. Rating Banks: Risk and Uncertainty in an Opaque Industry. The American Economic Review, 92(4):874-888, 2002.

Maureen O'Hara and Wayne Shaw. Deposit Insurance and Wealth Effects: The Value of Being "Too big to fail". The Journal of Finance, 45(5):1587-1600, 1990.

Michael T Owyang, Valerie A Ramey, and Sarah Zubairy. Are Government Spending Multipliers Greater During Periods of Slack? Evidence from Twentieth-century Historical Data. American Economic Review, 103(3):129-34, 2013.

Daniel Pérez, Vicente Salas-Fumás, and Jesús Saurina. Earnings and Capital Management in Alternative Loan Loss Provision Regulatory Regimes. European Accounting Review, 17(3):423-445, 2008.

Frédéric Pesme. France's “Return” to NATO: Implications for its Defence Policy. European security, 19(1):45-60, 2010.

Valerie A Ramey. Identifying Government Spending Shocks: It's All in the Timing. The Quarterly Journal of Economics, 126(1):1-50, 2011.

Valerie A Ramey and Matthew D Shapiro. Costly Capital Reallocation and the Effects of Government Spending. In Carnegie-Rochester Conference Series on Public Policy, volume 48, pages 145-194. Elsevier, 1998. 
Valerie A Ramey and Sarah Zubairy. Government Spending Multipliers in Good Times and in Bad: Evidence from US Historical Data. Journal of Political Economy, 126(2):850-901, 2018.

Julio J Rotemberg and Michael Woodford. An Optimization-based Econometric Framework for the Evaluation of Monetary Policy. NBER Macroeconomics Annual, 12:297-346, 1997.

Stefan Simons. Sarkozy Breaks with De Gaulle and Tradition. Spiegel Online, Mar 2009. URL http://www.spiegel.de/international/europe / france-s-return-to-nato-sarkozy-breaks-with-de-gaulle-and-tradition-a-612840. html.

Gary H Stern and Ron J Feldman. Too Big to Fail: The Hazards of Bank Bailouts. Brookings Institution Press, 2004. 